

\section{DISCLAIMER}

This report was prepared as an account of work sponsored by an agency of the United States Government. Neither the United States Government nor any agency Thereof, nor any of their employees, makes any warranty, express or implied, or assumes any legal liability or responsibility for the accuracy, completeness, or usefulness of any information, apparatus, product, or process disclosed, or represents that its use would not infringe privately owned rights. Reference herein to any specific commercial product, process, or service by trade name, trademark, manufacturer, or otherwise does not necessarily constitute or imply its endorsement, recommendation, or favoring by the United States Government or any agency thereof. The views and opinions of authors expressed herein do not necessarily state or reflect those of the United States Government or any agency thereof. 


\section{DISCLAIMER}

Portions of this document may be illegible in electronic image products. Images are produced from the best available original document. 


\section{Progress Report \\ DEVELOPHENT \\ OF}

PLUTONIUM-BEARING FUEL MATERIALS

January 1 through March 31, 1963

AEC R\&D Contract AT $(30-1)-2389$

NUREC $P-104$

\section{Facsimile Prices 4,60 \\ Microfilm Price $\$$

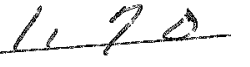 \\ Available from the Office of Technical Services Department of Commerce Washington 25, D. C.}

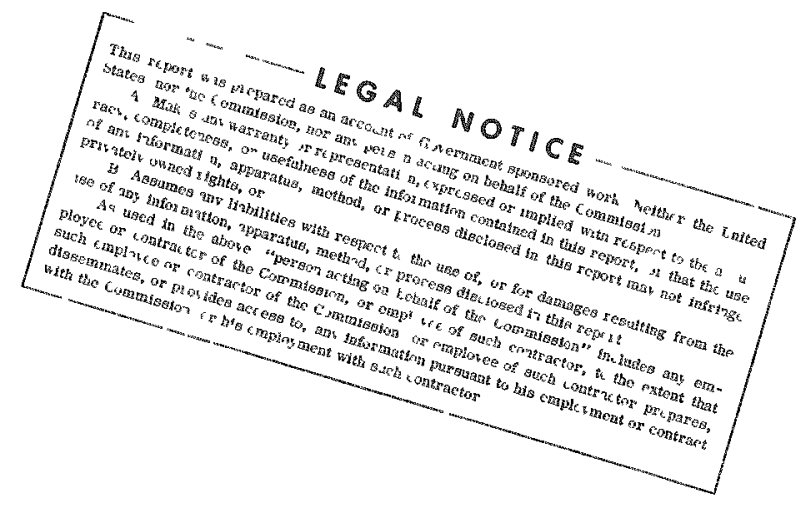

Nuclear Materials and Equipnent Corporation Apollo, Pennsylvania

For Official Use Only, Pending Patent Release 


\section{External Distribution}

U. S. Atomic Energy Commssion, New York Operations Office

N. Balicki, Research and Development Division

M. Plisner, Research Contracts and Technical Services Division

U. S. Atomic Energy Comission Washington

S. Christopher, Division of Reactor Development

R. Grube

Jo $M$. Simmons (2)

G. W. Vensch

Reports and Statistucs Branch

U. S. Atomic Energy Commission, National Laboratories F. Foote, Argonne National Laboratory

Library Services Department. Argonne National Laboratory (4)

I. Childs, Dow Chemical Company

D. A. Eschbach, Hanford Atomc Products Operation

T. A. Bvans, llanford Atomic Products Operation

Oc J. Wick, Ilanford Atomic Products Operation

J. Nusser, Wanford Atomic Products Operation

V. F. Roake, Hanford Atomc Products operation

W. Cashin, Knolls Atonic Power Laboratory

I. RIzzo. Lawrence Radiation Laboratory

F. A. Robertson California Patent Group

R. D. Baker: Los Alamos Scientific Laboratory

L. B. Jones, Mound Laboratory

R. I Mettlex, Dak Ridge National Laboratory (3)

D. F, Cope, Oak Ridge National Laboratury

E. S. Bomar" Oak Ridge National Laboratory

E. Jo Kreh. Westinghouse-Bettis Atomic Power Laboratory

U. S. Atomic Energy Commssion. Contractors

R. W. Dayton, Battelle liencrial Institute

R. F。 Dickerson, Battelle Menorial Institute

G. M. Butler, Jx, . Carborundura Company

K. Taylor, Carborundum Company

A. D, Schwope. Clente Research Center

Wo Alter. Vallecutos Atomic Power Laboratory

K. Cohen, General Electric Company San Jose

L. D. Harris. Mational Carbon Company

A. Strasser. United Nuclear Corporation

R. W. Hartwoll, Power Reactor Development Company

D. E. Ilamby, Union Carbide Iietals Company 
NUMEC Distribution

\begin{tabular}{|c|c|}
\hline R. Jo Atkins & D. C. Mckissick \\
\hline E. M. Benson & J. Marley \\
\hline F. M. Cain & 0. Menis \\
\hline C. S. Caldwell & $J, F$, Niles \\
\hline J. D. CIement & L. P. Pepkowitz \\
\hline B. W. Corroy & $\mathrm{K}, \mathrm{H}$. PuechI \\
\hline J. Eek & W. J. Ross \\
\hline Fo Forscher & Jo Roth \\
\hline II. Jo Garber & J. Ruzbacki \\
\hline Ro Wo Gerrish & J. Scott \\
\hline J. Goodnan & Z. H. Shapiro \\
\hline B. O. Grable & F, Shipko \\
\hline 0. S. Gray & Jo Stoner \\
\hline E. I. HaIteman & R. S. Strain \\
\hline So A. Maran & I. Do Thonas \\
\hline R. Mo Horgos & J. Io Poman \\
\hline M. Dn Houston & Ho Murkanis \\
\hline Lo Jo Jones & B. Vondra \\
\hline W. C. Judd & L. Weber \\
\hline Ao Kasberg & A. H. Weis \\
\hline Ho Wo Krake & 1:. Zambernard \\
\hline d. C. Limpert & Library \\
\hline
\end{tabular}


NUlvEC $P-104$

Previous Quarterly Progress Reports issued in this series are:

\begin{tabular}{|c|c|}
\hline NUPBER & FOR THE PERIOD ENDI \\
\hline NOHEC $P-10$ & December 31, 1959 \\
\hline NUMEC $\quad P-20$ & March 31, 1960 \\
\hline NUFEC $P-30$ & June 30,1960 \\
\hline NULEC $P-40$ & September 30, 1960 \\
\hline$M U T^{\prime} B C \quad P-50$ & December 31,1960 \\
\hline MUS $\mathrm{EC}-60$ & March 31, 1961 \\
\hline NUE:SC P-70 & June 30,1961 \\
\hline NUPEC $\quad P-80$ & September 30,1961 \\
\hline NUMEC $\mathrm{P}-90$ & Decenber 31, 1961 \\
\hline NUWEG $P=100$ & Piarch 31,1962 \\
\hline $\mathrm{NUW}_{2} \mathrm{LC} \quad \mathrm{P}-101$ & June 30,1962 \\
\hline NULEC P-102 & September 30,1962 \\
\hline NUTEC $\mathrm{P}-103$ & December 31,1962 \\
\hline
\end{tabular}




\section{PABLE OF COHTENTS}

PROJECT AND FACILITY ADMTMTSTRATION - TASK 1.00

Page Summary of Development Activities

General Plant and Project Aspects

PREPARATION AND CHARAGTERIZATION OF FULI MATERIALS - TASL 2.00 Preparation and Characterization of Plutonium Oxide

Preparation and Characteriation of Mixed Plutonium-Uranium Oxides Analytical Chemistry

FABRICATION AND EVALUAPION OF FUEL SHAPES - TASK $3.00 \quad 30$

$\mathrm{PuO}_{2}$ Sintering Studies

Mixed Oxide Sintering Studies

Production of Spherical Particles by Plasna Torch

Procuction of Spherical Particles by Aggloneration

Oxidation Kinetics of $\mathrm{UO}_{2} \mathrm{PuO}_{2}$

Physical Property Measurements

FUEL ELRHENT FABRICATION AND EVALUATION - TASK 4.00 Compatzbility Study Corrosion Tests

Short-Pern Irraduation Test Fuel Fabrication

42

42

42

RADTATION TBSTING AND RVALUATION - TASK 5.00

Short-Term Irradiation Tests

45

Hot Laboratory Bquipment Fabrication

45

45

REACTOR PHYSICS AID FNGINERTIIG PARAIETRIC STUDIES - TASK 8.00

47 Assessment of Plutonium in Near-Therral Reactors Fast Reactor Survey 
MUNTC $P-104$

\author{
PROJECT AND FACILITY ADIINISTRATION \\ Task 1.00 \\ $\mathrm{K}, \mathrm{H}$. Puechl
}

Summary of Development Activities

Three batches of $\mathrm{PuO}_{2}$ were prepared via the plutonium peroxide route to allow assessment of this process relative to the standard oxalate procedure. Except for the high tap density, it was found that the powder characteristics of $\mathrm{PuO}_{2}$ prepared in this manner are similar to the characteristics of $\mathrm{PuO}_{2}$ prepared by the oxalate route.

Because of the increased demand for mixed oxides for irradiation specimens and other studies, certain equipment modifications were made to achieve better reproducibility and to minimize operator time. Trial preparation rons were performed using the modified equipment. In one of these runs, armonia gas was evaluated as the precipitant relative to the previously used ammoniun hydroxide solution.

A study has been initiated to assess the feasibility of utilizing gama spectrometry for rapid in-process determination of plutonium in solutions that also contain uranium. For the initial investigations, the gamma radiation around the $60 \mathrm{Ker}$ plutonium and americium peaks was analyzed. The results indicated that plutonium can be determined to within $1 \%$ provided that the uranium concentration is known to better than $2 \mathrm{mg} / \mathrm{ml}$.

In preparation for burnup analysis of irradiated specimens, plutonium separation studies using TTA extraction have been continued and the determination of cesium and strontium fission products by flame photometry has been investigated. For the extraction studies the effect of trichloroacetic acid is being investigated. For the determination of cesiun and strontium by flame photometry, it was found that the relatively high background, especially in the case of strontium, could be significantly reduced by the use of perchloric acid. Fron these studies, it is concluded that interferences can be minimized or eliminated and that strontium and cesium can be determined with a relative standard deviation of $5-6 \%$.

Since previously performed sintering studies with $\mathrm{PuO}_{2}$ have yielded some as yet unexplained data, further studies were perforned. Specifically, the effect of carbon content cn the weight loss during sintering was deterinined. From these data $\mathrm{It}$ is concluded that residual carbon is not the cause of the extraneous results but that the exratic sintering behavior is probably due to residual moisture in the $\mathrm{N}_{2}-6 \% \mathrm{H}_{2}$ sintering a tmosphere.

Mixed oxide sintering studies were also continued. Metallographic examination of $\mathrm{UO}_{2}-35 \mathrm{w} / 0 \mathrm{PuO}_{2}$ pellsts indicates that the low densities obtained 
may be due to grain growth and broadening of grain boundaries during sintering,

As an alternate to the production of spherical particles for duspersiontype fuel elements, powder agglomeration studies have been initiated. Green spheres were formed in a snall mill jar, and the particle size distributions of both the formable and non-formable powder fractions were determined by centrifugal sedimentation size analysis. The results indicate that the finer particles in the porder are selectively "snowballed" into the spherical shape and the coarser particles are left behind in the residue.

To and in the interpretation of sintering data as well as to assess the effects of oxidizing environments, a study has been initiated to determine the oxidation kinetics of $\mathrm{VO}_{2}-\mathrm{PuO}_{2}$ by means of thermogravimetric analysis. To check out glove box procedures, preliminary runs were performed by oxidizing $\mathrm{VO}_{2}$ powder to U307: satisfactory results were obtained.

Preparation of duplex pellets for detcrmining the reaction between $\mathrm{UO}_{2}-\mathrm{PuO}_{2}$ and possible cladding ard diluent metals is continring, as is the associated metallographic and x-ray diffraction examination.

Pellets of nure $\mathrm{PuO}_{2}$ and $\mathrm{S} 1 \mathrm{~K}$ compositions of copreciplated $\mathrm{PuO}_{2}-\mathrm{HO}_{2}$ have been fabricated for corrosion testing 2 water and stean under a variety of water chemistry conditions. Preluminary tests performed in $750^{\circ}$ F-2200 psi steam for 10 hours showed no visual evidence of corrosion.

Al1 80 fuel elements for the short-term irradiation progran have now been fabricated and representatzwe pellets of the various compositions and density ranges are undergong detailed chemical, metallographic, and $x-r a y$ diffraction examination. The 14 fuel capsules have been loaded and shipped to the reactor site.

The Iusurp code has been nodified to aliow calculation of undernoderated systems. Bxperimental data on uraniun lattice neasurenents as vell as analytzeally derzyed data fron MUFT, REPRTTIOUS, and SOFOCATE codes are now being analyed to check the validity of the NUSURP code nodification prior to analysis of piutonium behavior in such systems.

\section{Genera I Plant and Project Aspects}

In preparation for the return of the short-term irradiation specimens, cffort is cortunuing on equipment installatzon within the alpha bozes. Such installation in the main hot cell alpha boxes and in the metallography cell alpha box is nearing completion. The Junior Cave itself is being modified prior to the installation of the alpha box which will house radionemistry equpneat for burnup analysis.

The installation of the IRC high temporature canera on a diffractometer within ar alpha box has been compieted. and this equipment is now ready for com trinent to plutonium. 


\title{
PREPARATION AND CHARACTERIZATION OF FUEL MATERIALS
}

\author{
Task 2.00 \\ C. S. CaIdwell O. Menis
}

$\frac{\text { Preparation and Characterization of plutonium Oxide }}{\left(G_{0} \text { Ehrich, } J_{0} \text { Goodman, Jo Limpert, } J_{0} \text { Roth) }\right.}$

Continued effort has been placed on screening runs to allow assessment of various $\mathrm{PuO}_{2}$ preparation routes relative to the standard oxalate procedure. During this period, the plutonium peroxide route was investigated by the preparation of three batches with each being prepared under slightly different process conditions.

\section{Plutonium Peroxide Preparation Route}

Three batches of plutoniun peroxide were precipitated by the addition of hydrogen peroxide strike solution to stirred, acidificd plutoniuri nitrate solution. Following oven drying, the peroxide was converted to $\mathrm{PuO}_{2}$ by air calcination at $490^{\circ} \mathrm{C}$. The process conditions utilized (Iisted in Table 2.1) were modifications of those used by Leary, et al $(i)$ and Orth, et al (ii).

The plutonium peroxides, in general, are not corpounds of well-defined stoichiometry; the ratio of oxygen to plutonium are non-integral with greater or lesser amounts of anions incorporated into the crystal lattice. The cubic or hexagonal form can be obtained depending upon process conditions, with the hexagonal form being preferred because of its granular nature and good filtration/washing properties. For stabilization or enhancement of the hexagonal form relative to the cubic, Leary recomended the incorporation of sulfate in the feed. In addition, both Leary and Orth stressed the need for "proper" agitation to minimize the regions of low acidity that tend to develop locally at the strike solution entry point since the cubic form is precipitated under low acid conditions.

For Run 297pu29 the procedure recomended by Leary was followed except that sulfate was not used since the sulfate jon is not readily removed. In short, the run was made in this manner to allow assessment of possible filtration difficulties in combination with a short calcination cycle relative to good filtration and longer higher temperature calcination. The wet precipitate was collected in 5 micron porous stainless steel filter cannisters previously

(1) Jo A, Leary, et aI, LA -1913.

(ii) Do Ao Orth et al, Industrial and Engineering Chemistry, Vol. 53, 9, p. 685, Septeriber 1961 . 
Table 2.1

$\mathrm{PuO}_{2}$ Preparation Conditions (Batch Plutonium Peroxide Route)

Plutonium Feed Solution

Batch Size, gra $\mathrm{Pu}$

Plutonium Concentration, gm/ 1

$\mathrm{H}^{+}$Concentration, $\mathrm{M}$

Suifamic Acid Concentration,

$\begin{array}{ccc}119.0 & 64.5 & 74.0 \\ 20.7 & 65.0 & 85.8 \\ 3.0 & 4.5 & 3.6 \\ - & 0.3 & 0.3 \\ & & \\ 30.0 & 50.0 & 30.0 \\ - & - & 3.0 \\ 0.07 & - & - \\ 0.342 & 0.240 & 0.260 \\ 0.707 & 0.500 & 0.482 \\ 18 & 7.1 & 4.3 \\ 760 & 700 & 700\end{array}$

Precipitant

$\mathrm{H}_{2} \mathrm{O}_{2}$ Reagent Strength, v/o

$\mathrm{H}+$ Concentration, M

Volume $\mathrm{H}_{2} \mathrm{O}_{2}$ Used for Plutonium Valence Adjustment, 1

Volume $\mathrm{H}_{2} \mathrm{O}_{2}$ Added Slowly, 1

Total Volume $\mathrm{H}_{2} \mathrm{O}_{2}$ Added, I

Addition Rate During Slow Addition, mI/min

Agitator Speed (2.5 in. dia flat turbine impellero), rpm

Precipitation Temperature, ${ }^{\circ} \mathrm{C}$

20

15

20

Digestion Conditions

Temperature, ${ }^{\circ} \mathrm{C}$

15

Tine, $\mathrm{hr}$

0.5

6

12

7

2.5

1.0

Filtration Iime min

4

9

Drying Conditions

Temperature, ${ }^{\circ} \mathrm{C}$

Time, hro

55
48

55
48

55

Calcination Conditions

Temperature, ${ }^{\circ} \mathrm{C}$

Time, hr

$\begin{array}{ccc}490 & 490 & 490 \\ 0.5 & 0.5 & 0.5\end{array}$


described.(i) X-ray diffruction of the precipitate indicated the presence of both the cubical and hexagonal forms. Powder patterns of oven aried material (dried at $55^{\circ} \mathrm{C}$ for 48 hours) were essentially amorphous with the presence of a faint broad $\mathrm{PuO}_{2}$ pattern. Filtration was very rapid, and the filtrate was a deep red color but was free of sediment. While standing for several days, the red color changed to a veak strav color, and some sediment formed. The excess hydrogen peroxide was subsequently "killed" by the addition of $\mathrm{NaOH}$ solution, and the "killed" filtrate was ciarified by further filtration. Alpha counting indicated that the plutoniur concentration in the waste liquid was about $4 \mathrm{mg} / \mathrm{li}^{2}$ ter. From the point of view of filtration alone, it was therefore concluded that the addition of sulfate into the feed is not necessary.

For Runs 297Pu30 and 297Pu31 sulfanic acid was added to the plutonium solution as suggested by Orth. The major difference between these two runs was the addition of $3 \mathrm{M} \mathrm{HNO}_{3}$ to the hydrogen peroxide strike solution in the case of Run 297Pu31. For both these runs, the filtration characteristics were similar to that of Run 297Pu29.

In all instances the dried filter cakes consisted of hard rigid lumps which covld, however, be readily crushed to granular powler. The dried cakes were calcined in lump form in flowing air at $490^{\circ} \mathrm{C}$ for 30 minutes. The converted materials had the same hard aggregate structure as the precursors: final comminution was by hammermilling using 10 mil herringbone screens.

The powder characteristics for all runs are tabulated in Table 2.20 It is seen that the characteristics of the product $\mathrm{PuO}_{2}$ are similar for all. materials produced; however ${ }_{3}$ the surface area of the precursor for Run 297 Pu29 is extremely low in comparison to the other two runs. Bxcept for the high tap density, the characteristics of the $\mathrm{PuO}_{2}$ are similar to those of $\mathrm{PuO}_{2}$ prepared by the standard oxalate route.

For Run 297Pu29, the particle size distribution of $\mathrm{PuO}_{2}$ is shom in Figure 2.1 along with previous results obtained with oxalate and hydroxide dercved material. It is seen that the distribution is nearly identical to that of hydroxide derived $\mathrm{PuO}_{2}$ and that these distributions lie midway between those obtalned on $\mathrm{PuO}_{2}$ from batch and continuous oralate routes.

The harmermiled products were analyzed for trace impurities; the results are presented in Table 2.3. The high levels of iron, maganese, chromium, and nickel are probably due to stainless steel corrosion during processing: however, the high carbon levels cannot be explained at this time.

(i) NUHC P-60, Progress Report, mevelopment of Plntonium-Bearing Fuel laterials", page 10 . 
described.(1) $X$-ray diffraction of the precipitate indicated the presence of both the cubical and hexagonal forms. Powder patterns of oven-dried material (dried at $55^{\circ} \mathrm{C}$ for 48 hours) were essentially amorphous with the presence of a faint broad $\mathrm{PuO}_{2}$ pattern. Filtration was very rapid, and the filtrate was a deep red color but was free of sediment. While standing for severel days, the red color changed to a veak straw color, and some sediment forned. The excess hydrogen peroxide was subsequently "killed" by the addition of $\mathrm{NaOH}$ solution, and the "killed" filtrate was clarified by further filtration. Alpha counting indicated that the plutonium concentration in the waste liquid was about $4 \mathrm{mg} / \mathrm{lit}$ ter. Fron the point of view of filtration alone. it was therefore concluded that the addition of sulfate into the feed is not necessary.

For Runs 297Pu30 and 297Pu31 sulfamic acid was added to the plutonium solution as suggested by Orth. The major difference between these two runs was the addition of $3 \mathrm{M} \mathrm{HNO}_{3}$ to the hydrogen peroxide strike solution in the case of Run 297Pu31. For both these runs, the filtration characteristics were similar to that of Run 297Pu29.

In all instances the dried filter cakes consisted of hard rigid lumps which covld, however, be readily crushed to granular powder. The dried cakes were calcined in lump form in flowing air at $490^{\circ} \mathrm{C}$ for 30 minutes. The converted materials had the same hard aggregate structure as the precursors: final comminution was by hamermilling using 10 mil herringbone screens.

The powder characteristics for all runs are tabulated in Table 2.2. It is secn that the characteristics of the product $\mathrm{PuO}_{2}$ are similar for all materials produced; however, the surface area of the precursor for Run 297Pu29 is extremely low in comparison to the other two runs. Except for the high tap density the characteristics of the $\mathrm{PuO}_{2}$ are similar to those of $\mathrm{PuO}_{2}$ prepared by the standard oxalate route.

For Run 297Pu29, the particle size distribution of $\mathrm{PuO}_{2}$ is shom in Figure 2.1 along with previous results obtained with oxalate and hydroxide derived material. It is seen that the distribution is nearly identical to that of hydroxide derived $\mathrm{PuO}_{2}$ and that these distributions Ile midway between those obtained on $\mathrm{PuO}_{2}$ from batch and continuous oxalate routes.

The hamemniled products were analyzed for trace impurities: the results are presented in Table 2.3. The high levels of iron, maganese, chromium, and nickel are probably due to stainless steel corrosion during processing; however, the high carbon levels cannot be explained at this time.

(i) NUREC P-60, Progress Report, "Developnent of Plutoniun-Bearing Fuel Naterials", page 10 . 
Table 2.3

Trace Impurities in Hammermilled $\mathrm{PuO}_{2}$ Produced via the Peroxide Route

(parts per million)

\begin{tabular}{|c|c|c|c|c|c|c|c|c|c|c|c|c|c|c|c|}
\hline $\begin{array}{l}\text { Sample } \\
\text { Number }\end{array}$ & $\mathrm{Fe}$ & $B$ & $\mathrm{Cd}$ & $\mathbb{M n}$ & $\mathrm{W}$ & $\underline{\mathrm{Ng}}$ & $\mathrm{Sn}$ & $\mathrm{Cu}$ & $\mathrm{Pb}$ & $\mathrm{Cn}$ & Si & $\mathbb{N i}$ & Mo & $v$ & C \\
\hline 297 Pu29 & 800 & 1 & 2 & 50 & 0 & 70 & 10 & 10 & 15 & 60 & 5 & 60 & 5 & 0 & 800 \\
\hline 297Pu30 & 400 & 1 & 1 & 50 & 0 & 10 & 5 & 10 & 10 & 300 & 1 & 50 & 10 & 0 & 320 \\
\hline 297Pu31 & 500 & 1 & 1 & 80 & 0 & 40 & 5 & 10 & 10 & 300 & 1 & 80 & 10 & 0 & 310 \\
\hline
\end{tabular}




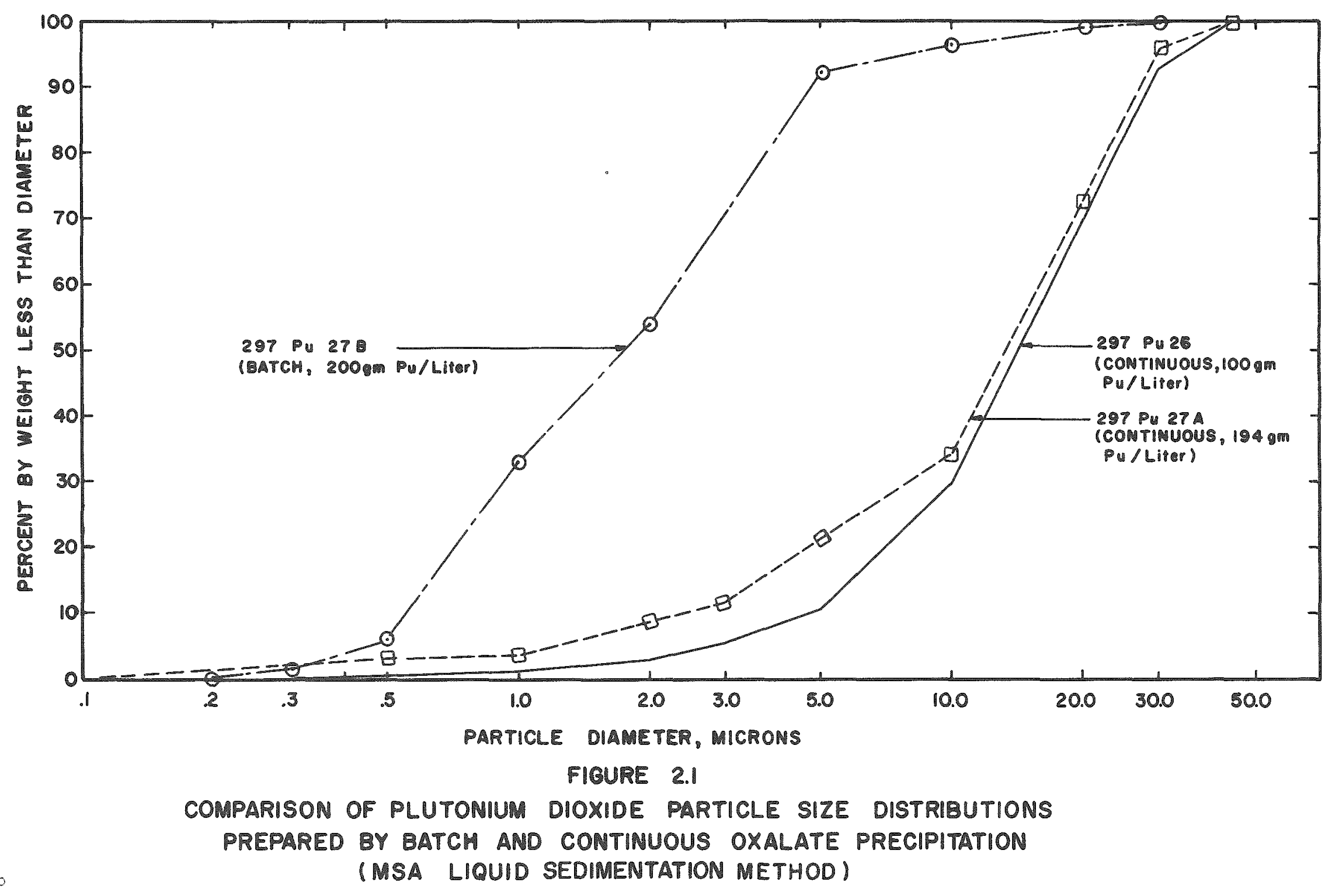


NUPEC $P-104$

Investigation of this preparation route will be extended to continuous precipitation only if sintering studies on the batch materials indicate significant improvement over oxalate derived product.

\section{Preparation and Characterization of Mixed Plutonium-Uranium Oxides} (G. Ehrlich, J. Goodman)

With the increased demand for mixed oxides for sintering studies, compatibility studies and irradiation specimens considerable effort during this period has been placed on the modification of equipment to achieve better reproducibility and to miniraize operator time. In addition to these equipment modifications, three continuous coprecipitation runs were carried out.

Initially, U/Pu nitrate feed and aqueous annonium hydroxide solutions were metered into the precipitator from constant head reservoirs using valves and rotameters; to maintain constant flow rates with this system required constant operato attention. This situation had been improved to some extent, by the installation and use of pulsating diaphragm constant displacement (IAPP) metering pumps. Experience has shom that these pumps can be operated for U/Pu nitrate feed service over extended periods of time without drift of feed rate and thereby without operator attention. However, similar experience has indicated difficulty when these pumps were used for metering concentrated ammonium hydroxide solutions; specifically, the dissolved ammonia gas volatalizes and causes vapor locking in the pump cavity, and this produced erratic or, at tires, complete stoppage of flow. This situation has been somewhat improved by the installation of springloaded pressure check valves into the purn discharge line. However, because of this difficulty, the system was further modified to allow the use of anhydrous ammonia gas. Ammonia gas can now be metered into the botton of the precipitator directly from a liquified amonia cylinder through a regulator valve and rotameter equipped with a flow controller.

A new precipitator has also been designed and installed. This unit contains a series of 4 vertical baffles to reduce the vortex of the stirred slurry and thereby to increase turbulance and pronote better mixing. In addition, a conductivity probe was also installed to allow automatic control of the slurry level through activation of a solenoid valve installed at the withdrawal port. This unit is shom in Figure 2.2.

The three preparation runs were carried out to obtain $\mathrm{UO}_{2}-80 \mathrm{w} / \mathrm{O} \mathrm{PuO}_{2}$ material for compatibility studies, to determine the effect of using concentrated aqueous ammonia as precipitant for $\mathrm{UO}_{2}-12.5 \mathrm{~W} / \mathrm{O} \mathrm{PuO}_{2}$ and to check out the equipment on $\mathrm{UO}_{2}-5 \mathrm{w} / \mathrm{PuO}_{2}$ using gaseous amonia as precipitant. For the latter wo runs, the precipitates produced during startup and shut-down were segregated from the steady-state material as was done previously. The preparation conditions for the three runs are presented in Table $2.4 \%$ Powder property data are tabulated in Table 2.5. 
Table 2.4

Surmary of Preparation Data for Coprecipitated $\mathrm{UO}_{2}-\mathrm{PuO}_{2}$ Paterials

\begin{tabular}{|c|c|c|c|c|c|}
\hline Run Identification & 297Pu28 & \multicolumn{4}{|c|}{$297 P u 33$} \\
\hline Composition & $\mathrm{UO}_{2}-80 \mathrm{w} / \mathrm{O} \mathrm{PuO}_{2}$ & \multicolumn{4}{|c|}{$\mathrm{UO}_{2}-12.5 \mathrm{w} / \mathrm{O} \mathrm{PuO}_{2}$} \\
\hline $\begin{array}{l}\text { Precipitation Conditions } \\
\text { Irethod } \\
\text { Temperature, }{ }^{\circ} \mathrm{C}\end{array}$ & $\begin{array}{l}\text { Continuous } \\
55\end{array}$ & $\begin{array}{l}\text { Continuous } \\
55\end{array}$ & \multicolumn{2}{|c|}{$\begin{array}{l}\text { Continuous } \\
55\end{array}$} & $\begin{array}{l}\text { Continuous } \\
55\end{array}$ \\
\hline $\begin{array}{c}\text { Feed Composition } \\
\text { gn Pu/Iiter } \\
\text { gn U/Iiter } \\
\text { TI }^{+} \text {, molarity }\end{array}$ & $\begin{array}{r}77.8 \\
20.0 \\
1.0 \\
\end{array}$ & $\begin{array}{r}12.5 \\
87.5 \\
1.0 \\
\end{array}$ & \multicolumn{2}{|c|}{$\begin{array}{r}12.5 \\
87.5 \\
1.0\end{array}$} & $\begin{array}{r}12.5 \\
87.5 \\
1.0 \\
\end{array}$ \\
\hline Feed Flow Rate, Iiters/hr & 1,2 & 1.2 & \multicolumn{2}{|c|}{1,2} & 1.2 \\
\hline $\begin{array}{l}\text { Precipitant Composition } \\
\text { NH }_{4} \text { OH, molarity }\end{array}$ & 14.5 & 14.5 & \multicolumn{2}{|c|}{14,5} & 14.5 \\
\hline $\begin{array}{l}\text { Precinitant Flow Rate } \\
\text { liters/hr }\end{array}$ & 0.43 & 0.23 & \multicolumn{2}{|c|}{0.23} & 0.23 \\
\hline $\begin{array}{l}\text { Precipitation Average Holdup, } \\
\text { minutes }\end{array}$ & 28.4 & 32.0 & \multicolumn{2}{|c|}{32,0} & 32,0 \\
\hline Tota I Ilumber Throughouts & 2.9 & 3.0 & \multicolumn{2}{|c|}{5.5} & 1,0 \\
\hline Run Period & Total & Start Up & \multicolumn{2}{|c|}{ Steady State } & Shut Down \\
\hline Oxide Sample Identification & 292 Pu28 & $1580-240$ & $S S 80=640$ & $5580-840$ & $8580-240$ \\
\hline Drying Temperature ${ }^{\circ}$ & 180 & 180 & 180 & 180 & 180 \\
\hline Gas A tmosphere & $N_{2}-6, \mathrm{H}_{2}$ & $\mathrm{~N}_{2}-6 ; \mathrm{H}_{2}$ & $\mathrm{~N}_{2}-6 \% \mathrm{H}_{2}$ & $\mathrm{~N}_{2}-6, \mathrm{H}_{2}$ & $\mathrm{~N}_{2}-6, \mathrm{H}_{2}$ \\
\hline Gas Flow, SCFH & 4.5 & 4.5 & 4,5 & 4,5 & 4.5 \\
\hline $\begin{array}{l}\text { Rate of Tenperature Climb. } \\
\text { o } / \min \end{array}$ & 12 & 12 & 12 & 12 & 12 \\
\hline Conversion Temperature ${ }^{\circ} \mathrm{C}$ & 840 & 240 & 640 & 840 & 240 \\
\hline $\begin{array}{l}\text { Tire at Conversion Temperature, } \\
\text { min }\end{array}$ & 80 & 80 & 80 & 80 & 80 \\
\hline Furnace Charge, gm & 125.2 & 121.9 & 218,0 & 224.6 & 156.2 \\
\hline
\end{tabular}

(Continued) 
Table 2.4 (Continued)

Summary of Preparation Data

for Coprecipitated UO 2 -PuO 2 Iaterials

\begin{tabular}{|c|c|c|c|c|}
\hline Run Identification & \multicolumn{4}{|c|}{$297 P u 34$} \\
\hline Composition & \multicolumn{4}{|c|}{$\mathrm{UO}_{2}-5 \mathrm{k} / 0 \mathrm{PuO}_{2}$} \\
\hline $\begin{array}{l}\text { Precipitation Conditions } \\
\text { Hethod } \\
\text { Temperature, }{ }^{\circ} \mathrm{C}\end{array}$ & \multicolumn{4}{|c|}{$\begin{array}{l}\text { Continuous } \\
55\end{array}$} \\
\hline $\begin{array}{l}\text { Feed Composition } \\
\text { gm Pu/liter } \\
\text { gn U/Iiter } \\
H^{+} \text {molarity }\end{array}$ & \multicolumn{4}{|c|}{$\begin{array}{r}5.0 \\
95.0 \\
1.0\end{array}$} \\
\hline Feed Flow Rate, liters/hr & \multicolumn{4}{|c|}{1.1} \\
\hline Precipitant & \multicolumn{4}{|c|}{ Anyhdrous Gaseous Ammonia } \\
\hline Precipitant Flow Rate SCFH & \multicolumn{4}{|c|}{0.034} \\
\hline Precipitation Average Holdup min & \multicolumn{4}{|c|}{60} \\
\hline Total Number Throughputs & 3 & 5,4 & 54 & 1 \\
\hline Run Period & Start Up & Ste & State & Shut Doun \\
\hline Oxide Sample Identification & $T S 80-740$ & $5580-640$ & 5580.840 & $8580=240$ \\
\hline Drying Temperature $\mathrm{C}$ & 180 & 180 & 180 & 180 \\
\hline Conversion Gas Atrosphere & $\mathrm{H}_{2}-6 \% \mathrm{H}_{2}$ & $\mathrm{~N}_{2}-68 \mathrm{H}_{2}$ & $\mathrm{~N}_{2}-6 \mathrm{H}_{2}$ & $\mathrm{H}_{2}-6 \mathrm{H}_{2}$ \\
\hline Conversion Gas Fow Rate, SCFH & 4.5 & 4.5 & 4.5 & 4.5 \\
\hline Rate of Temperature Climb olmin & 12 & 12 & 12 & 12 \\
\hline Conversion Temperature oC & 240 & 640 & 840 & 240 \\
\hline Time at Conversion ienperature min & 80 & 80 & 80 & 80 \\
\hline Furnace Charge. gra & 2024 & 420.0 & 490,1 & 20.0 \\
\hline
\end{tabular}


Table 2.5

\begin{tabular}{|c|c|c|c|c|c|c|c|}
\hline $\begin{array}{l}\text { Sample } \\
\text { Number }\end{array}$ & $\begin{array}{l}\text { Oxygen/Metal } \\
\text { Ratio in } \\
\text { Uranium } \\
\text { Fraction }\end{array}$ & $\begin{array}{l}\text { B.E.To } \\
\text { Surface } \\
\text { Area } \\
M^{2} / \mathrm{gm}\end{array}$ & $\begin{array}{l}\text { Bulk } \\
\text { Density } \\
\text { gm/cc }\end{array}$ & $\begin{array}{c}\text { Tap } \\
\text { Density } \\
\mathrm{gm} / \mathrm{cc}\end{array}$ & $\begin{array}{c}\text { Air Permeability } \\
\text { Particie size } \\
\text { microns }\end{array}$ & $\begin{array}{l}\text { Mverage MSA } \\
\text { Particle Size } \\
\text { for - } 200 \text { mesh } \\
\text { Fraction } \\
\text { microns }\end{array}$ & $\begin{array}{l}\text { W/o } \\
\text { Greater Than } \\
74 \text { microns } \\
(200 \text { mesh) }\end{array}$ \\
\hline 297Pu28 & $\infty$ & 5.2 & 3.43 & 6.07 & 3.9 & 5.8 & $<2$ \\
\hline Pu 33 TS $80=740$ & - & 9.6 & $\infty$ & $=$ & - & $=$ & $=$ \\
\hline Pu $335580-640$ & 2.27 & 12.5 & 0.71 & 1.55 & 0.82 & 4.2 & 45 \\
\hline Pu335580-840 & 2.15 & 9.0 & 0.70 & 1.84 & 0,37 & 1.2 & $<2$ \\
\hline Pu33RS80-740 & $\infty$ & - & - & $=$ & - & $\infty$ & - \\
\hline
\end{tabular}

* Powder properties measured for hammermilled powders. 
NUMEC $\mathrm{P}-104$

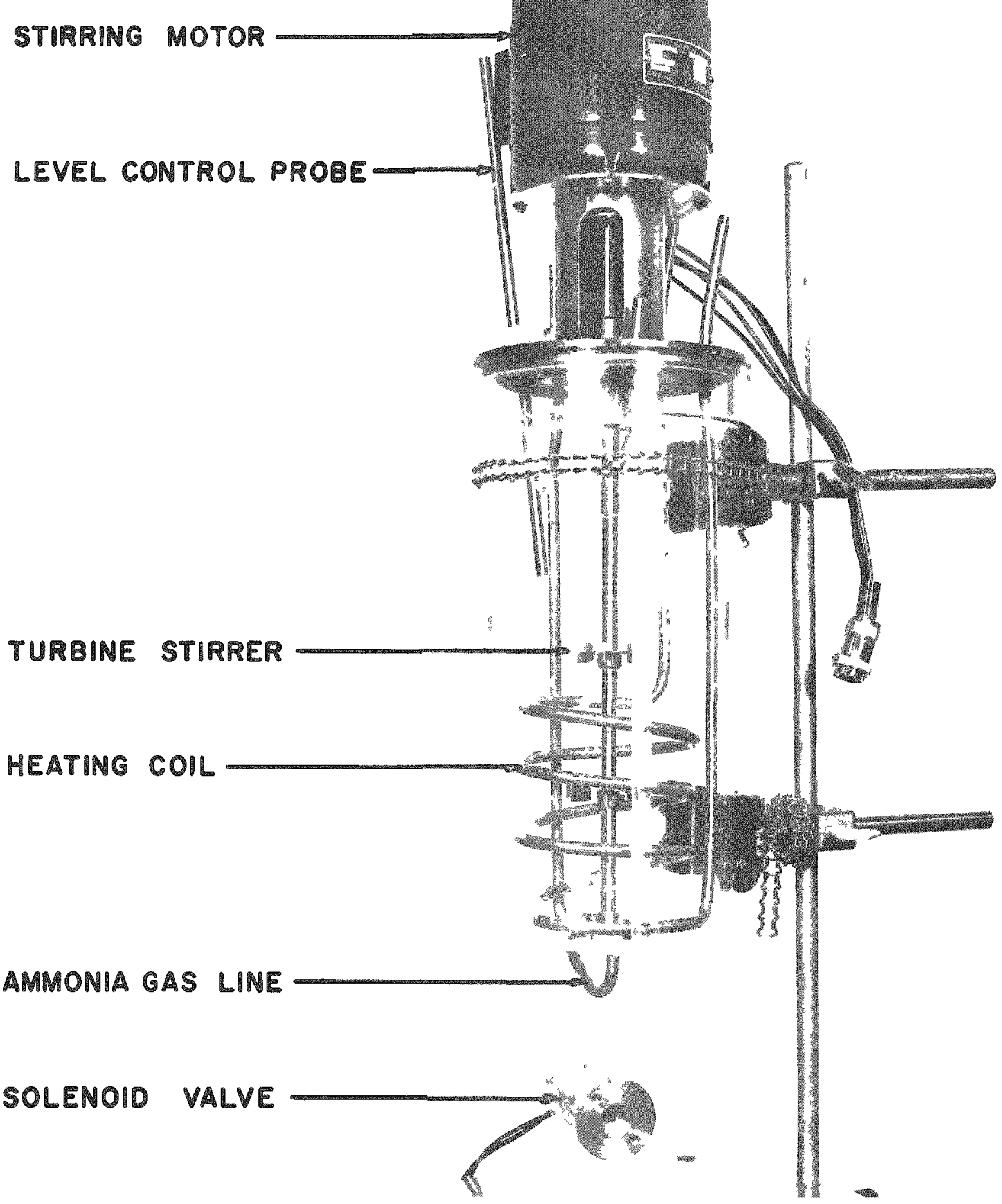

Figure 2.2

Four-Liter Continuous Precipitator 
The $\mathrm{UO}_{2}-80 \mathrm{w} / \mathrm{O} \mathrm{PuO}_{2}$ (Run 297Pu28) precipitate was dried overnight at $180^{\circ} \mathrm{C}$ and converted to oxide powder by calcining for 80 minutes at $840^{\circ} \mathrm{C}$ in an $\mathrm{N}_{2}-6 \% \mathrm{H}_{2}$ atmosphere. Final powder cominution was performed by hamermilling using $10 \mathrm{mil}$ herringbone screens. The extraordinarily high tap density $(6.8 \mathrm{gm} / \mathrm{cc}$ ) and large Fisher subsieve particle size ( 3.9 microns) suggested poor sinterability, and this was verified. Sintered pellet densities were low, generally approxinately $84 \%$ of theoretical.

Run 297Pu33 $\left(\mathrm{VO}_{2}-12.5 \mathrm{w} / \mathrm{O} \mathrm{PuO}_{2}\right)$ was made prior to the previously described equipment modifications and was intended to be a repetition of Run 297Pu20 in order to clarify seemingly abnormal behavior. However, early in the run, the pump in the ammonium hydroxide feed system becane vapor locked and thereby the flow rate was drastically reduced. Unreacted U/Pu nitrate was carried into the filtrate as indicated by the presence of postoprecipitated material in the waste receiver tanks. The continuous run was promptly terminated, and excess ammonium hydroxide was added to the remaining precipitator slurry. In order to assess the effects of such a major process upset, the precipitate was carried through the standard drying, calcination and reduction cycles, and the powder properties were compared to those obtained under the standard conditions in Run 297pu20. This corparison is shown in Table 2.6. With the exception of the large agglomerate size of $297 \mathrm{Pu} 33$ powder calcined at $640^{\circ} \mathrm{C}$ and the high surface area $\left(9.0 \mathrm{Im}^{2} / \mathrm{gm}\right)$ of the powder calcined at $840^{\circ} \mathrm{C}$, comparable powder specimens from the two runs have similar characteristics. It is therefore concluded that the final powder characteristics are not very sensitive to this type of process upset: as indicated by previous investigations, the powder characteristics are detemined primarily by the dry conversion conditions.

In Run 297Pu34, $\mathrm{VO}_{2}-5 \mathrm{~m} / \mathrm{O} \mathrm{PuO}_{2}$ was prepared by using gaseous ammonia as precipitant in order to check out the equiphent and to demonstrate process control. The precursor was air-dried at $180^{\circ} \mathrm{C}$ for 16 hours and was converted in $\mathrm{N}_{2}-6 \% \mathrm{H}_{2}$ at temperatures of 640,740 , and $840^{\circ} \mathrm{C}$. These materials are presently being characterized.

$$
\text { (0. Henis, Wo Judd, Jo Limpert, Bo Conroy) }
$$

A study has been initiated to assess the feasibility of utilizing gama spectrometry for rapid inmprocess deternination of plutoniun in solutions that also contain uranium. Further, in preparation for burnup analysis of irradiated specimens, plutoniun separation studies using TTA extraction have been continued, and determination of cesium and strontiun fission products by flane photonetry has been investigated.

Determination of Plutonim in Plutonium-Uxanium Solutions by Gamea Spectronetry

Analyzing for plutonium by gama spectrometry is conplicated by the variability of plutonium isotopic composition and variability in higher isotope (primarily 
Table 2.6

Comparison of Powder Characteristics of Specimens of $\mathrm{UO}_{2}=12.5 \mathrm{w} / \mathrm{O} \mathrm{PuO}_{2}$

\begin{tabular}{|c|c|c|c|c|c|c|c|}
\hline Sample Number & $\begin{array}{l}\text { Oxygen/Mital } \\
\text { Ratio in } \\
\text { Uranium } \\
\text { Fraction }\end{array}$ & $\begin{array}{l}\text { B.E.T. } \\
\text { Surface } \\
\text { Area } \\
\mathrm{N}^{-2} / \mathrm{gm}^{2}\end{array}$ & $\begin{array}{l}\text { Bulk } \\
\text { Density } \\
\text { gm/cc }\end{array}$ & $\begin{array}{c}\text { Tap } \\
\text { Density } \\
\text { gyilco }\end{array}$ & $\begin{array}{c}\text { Fisher } \\
\text { Sub-wieve } \\
\text { Partiole } \\
\text { Size } \\
\text { microns }\end{array}$ & $\begin{array}{l}\text { MSA } \\
50 \% \text { Particle } \\
\text { Size } \\
\text { microns }\end{array}$ & $\begin{array}{l}\text { Greater Than } \\
74 \text { microns } \\
\text { (200 mesh) }\end{array}$ \\
\hline 297Pu20 $5580-640$ & 2.28 & 11.7 & 0.68 & 1.91 & 0.30 & 2.5 & 3 \\
\hline 297Pu335s80-640 & 2.27 & 12.5 & 0.71 & 1.55 & 0.82 & 4.2 & 45 \\
\hline 297Pu20S580-840 & 2.17 & 6.8 & 0.74 & 2.08 & 0.40 & 1.0 & $<2$ \\
\hline 297Pu $335580-840$ & 2.15 & 9.0 & 0.70 & 1.84 & 0.37 & 1,4 & $<2$ \\
\hline
\end{tabular}

* Powder properties measured for hammermilled powders, 
americium) content. This difficulty, however, can be overcoine by preparing standard samples from stock solution and first analyzing these for plutonium content by amperometric titration.

Further difficulties are encountered in the presence of uranium or other heavy or radioactive elements due to gama background and/or self-shielding within the mediun. The presence of such elements must therefore be known or must be ascertained prior to interpretation of garma spectrometry results.

For the initial investications, the garma radiation around the $60 \mathrm{kev}$ plutoniun and anericium peaks was analyzed. The results are presented in Table 2.7 for solutions containing $4 \mathrm{mg} / \mathrm{ml}$ of uranium. It is seen that there is a slight increase in self-shielding over the range of plutonium concentration investigated $(5.4$ to $54.0 \mu \mathrm{g} / \mathrm{ml})$. For in-process control, this small self-shielding effect can be neglected.

To determine the self-shielding effect of larger concentrations of uranium (as might be present in $\mathrm{PuO}_{2} / \mathrm{UO}_{2}$ fuel mixtures), measurements were repeated with a uranium concentration of $50 \mathrm{mg} / \mathrm{ml}$. These data indicate a $23 \%$ reduction in activity, or that a $2 \mathrm{mg} / \mathrm{ml}$ change in uranium concentration results in a $1 \%$ change in the counting rate. In practice then, for $1 \%$ accuracy in the determination of plutonium, the uranium concentration must, be known to better than $2 \mathrm{mg} / \mathrm{ml}$.

Develoment of Analytical Procedures for the Determination of Fuel Burnup

For evaluation of both the short-term and high-burnup test specimens, the integrated fission energy must be determined. Normally, bwo methods are used; nanely, mass spectrometric determination of fissionable nuclides and radiochemical determination of isolated fission products, (i) For the short-term tests, the amount of fissile material depletion is sual1; therefore, essentially complete reliance must be placed on fission product analysis. Further, for $\mathrm{VO}_{2}-\mathrm{PuO}_{2}$ fuels, the interpretation of all data is

(i) Bo Fo Rider, et al, "The Deterination of Uranium Burnup in MW/Ton", GRAP-3373.

C. Bo Crouthamel, Ro Heimich, and $C_{0}$ Gatrousis, The Quantitative Determination of Fission and Nuclear Reactor Products", Talanta 1, 346-407 (1958).

D. No Sunderman "The Radiochemical Determination of Uranium Burnup" Paper Presented at ASTi Meeting at San Francisco, Dotober 11=16, 1959. 
NUNEC Po 104

Table 2.?

Determination of Plutonium by Gamma Spectrometry

Bnergy Analyzed: $60 \mathrm{kev}$

Uranium Concentration: $4 \mathrm{mg} / \mathrm{mI}$

\begin{tabular}{|c|c|c|}
\hline Plutonium $/ \mathrm{g} / \mathrm{ml}$ & Counts per Minute & Counts per Hinute/ $\mu \mathrm{g}$ Pu(i) \\
\hline 5.4 & 10,984 & 203.4 \\
13.5 & 27,072 & 200.5 \\
27.0 & 54.333 & 201.3 \\
54.0 & 106,408 & 197.0 \\
\hline & Average & 1.5 \\
\hline
\end{tabular}

(i) Corrected for uraniun background. 
difficult since more than one fissile nuclide is present, since fissile nuclides are being formed as well as destroyed, and since fission product yields from the various nuclides are not well-known.

For the short-term tests, we plan to rely primarily on the radiochemical detemination of Cs-137. Although this fission product forms a volatile compound and therefore tends to diffuse away from the point of formation, this is not serious in the short-term tests since high temperatures will not be maintained for extended periods of time. However, because of this volatility, $5 \mathrm{r}-90 \mathrm{w}$ w1 also be deterrined in the high burmup samples since this fission product forms a refpaptory oxide. Unfortunately, the half-life of $5 r^{-90}$ is not accurately knom ${ }^{1}$ and the yield from Pu-239 fissioning has not yet been established.

In general terms, the procedure will be to sample the fuel specimen, dissolve it in nitric acid, and separate out the plutoniun in hot cell alpha boxes. Aliquots from the plutonium-free specimens can then be analyzed for $\mathrm{CS}-137$ and $S \mathrm{r}-90$ by flatue photonetry in a chemical hood.

Separation of Plutoniur: Plutonium separation studies have been continued(ii) using thenoyltrifluoroacetone (TTA). In particular, the effect of trichloroacetic acid on the extraction rate is being investigated. The results presented in Table 2.3 show that equilibrium is reached vory rapidly rith vigorous shaking but that a reversal occurs after prolonged shaking. This reversal iay be due to a side reaction, such as reduction of Pu-IV to Pu-III. These observations are similar to the experiences of other investigators, who worked with differen systems. In particular, Ieisice and Hicks willing with the secondary butyl benzene-IMA-nitric acid system, noted the strong fffect of phase miring on the eitraction rate; and Cunninghane and Wiles $(i v)$ working with carbon tetrachlorile as the solvent, noted reversal after prolongod shaking.

(i) Jo Ro Rein and B. F。Rider, TID-17385, 1963, p. 18.

(ii) WuEC P-102, Progress Report, MDeveloplient of Plutoniur-Bearing Fuel Materials" page 24

(iii) D. Lo Heisi $E_{\text {and }} \mathrm{T}$. F。 Hicks, UCRL-1169, 1952.

(iv) Jo Go Cunninghame and G. L. Miles, J. Inorg. Chem, 2, 154 (1956). 
Table 2.8

Rate of Extraction of Pu-TTA Chelate from Trichloroacetic Acid Hedium

Organic, o: Xylene

Aqueous, a: 11 Mrichloroacetic Acid

$a / 0=1$

\begin{tabular}{|c|c|c|}
\cline { 2 - 3 } \multicolumn{1}{c|}{} & \multicolumn{2}{|c|}{ Percent Extracted } \\
\hline Time, min & $\begin{array}{c}\text { Equilibration(i) } \\
\text { Rocking Motion }\end{array}$ & $\begin{array}{c}\text { Equilibration(ii) } \\
\text { Hand Shaking }\end{array}$ \\
\hline 1 & - & 99.995 \\
2 & 94.8 & - \\
3 & 95.6 & 99.995 \\
5 & 98.1 & 98.1 \\
7 & 98.1 & - \\
10 & $97 . ?$ & - \\
60 & 97.1 & - \\
\hline
\end{tabular}

(i) Rocking Motion - Slow rocking motion (2 inversions/min) on an electrically driven rocker.

(ii) Hand Shaking - Vigorous shaking to produce unstable evolution. 
Determination of $\mathrm{Cs}$ and $\mathrm{Sr}$ by Flame Photometry: Following the procedures used in the other laboratories to analyze for impurities in plutonium $(i)$, flame photometry has been investigated as a reans for determining cesium and strontium content. For this purpose, the experimental apparatus was installed in a chemical hood as shom in Figure 2.3. Equipment used was a Beckman DU spectrophotometer with a flame attachment, spectral energy recording attachment and power supply and a Sargent Model IIR recorder having a one-second response. Rotameters were used to control the flow of oxygen and hydrogen. To collect traces of plutonium aspirated into the flane, a three-section chiney was constructed above the burner; absolute filters rere contained in the center section, and the chimey was connected to a high speed blower to provide positive air movernent through the filters.

In general, samples for analysis were prepared from 10 gran lots of $\mathrm{VO}_{2}-\mathrm{PuO}_{2}$. The mixed oxide was first dissolved in dilute (1-1) nitric acid by one hour exposure over a stean bath. The liquid was then filtered, and the plutonium was extracted with TMA. From the aqueous phase, $10 \mathrm{ml}$ aliquots vere then transferred to beakers containing $3 \mathrm{~m} 5 \mathrm{ml}$ perchloric acid, and the solutions were funed to near dryness. Upon cooling, the residues crystallized, and these crystals were dissolved in $0.2 \mathrm{~N} \mathrm{HNO}_{3}$ and diluted to $25 \mathrm{mI}$ samples. In those cases when the standard addition technique vas used, additions were made prior to dilution.

These solutions vere atomized into the flare, and the emissions at $460.7 \mathrm{~m} /$ and $852 \mathrm{mp}$ were measured. The optimum instrumental conditions are shom in Pable 2.9. While a slit width as large as $0.15 \mathrm{~mm}$ can be tolerated for cesium analysis at $852 \mathrm{~m}$, the silt width for strontiun analysis at 460.7 mp must be reduced to $0.03 \mathrm{~mm}$ due to spectral interferences.

$$
\text { Table } 2.9
$$

Instrumental Conditions for Determination of Strontium and Cesium by Flame Photometry

\section{Beckinan DU Wavelength Slit Width Sensitivity} Phototube Resistor Phototube, volts per dynode oxygen-to-Iydrogen Ratio*

$\frac{\text { Strontius: }}{460.7 \mathrm{~mm}}$
$0.03 \mathrm{~mm}$
70.9
22 mecohns
60
0.210

* Kontes rotaneters were used to control gas flow rate.

(i) Ro Fo Buchanan, Jo Po Faris, $K_{0} A_{0}$ Orlandini, and $J_{0} P_{0}$ ltughes, TID-7650, pp. 179-188, June 1958. 
NUMEC P-104

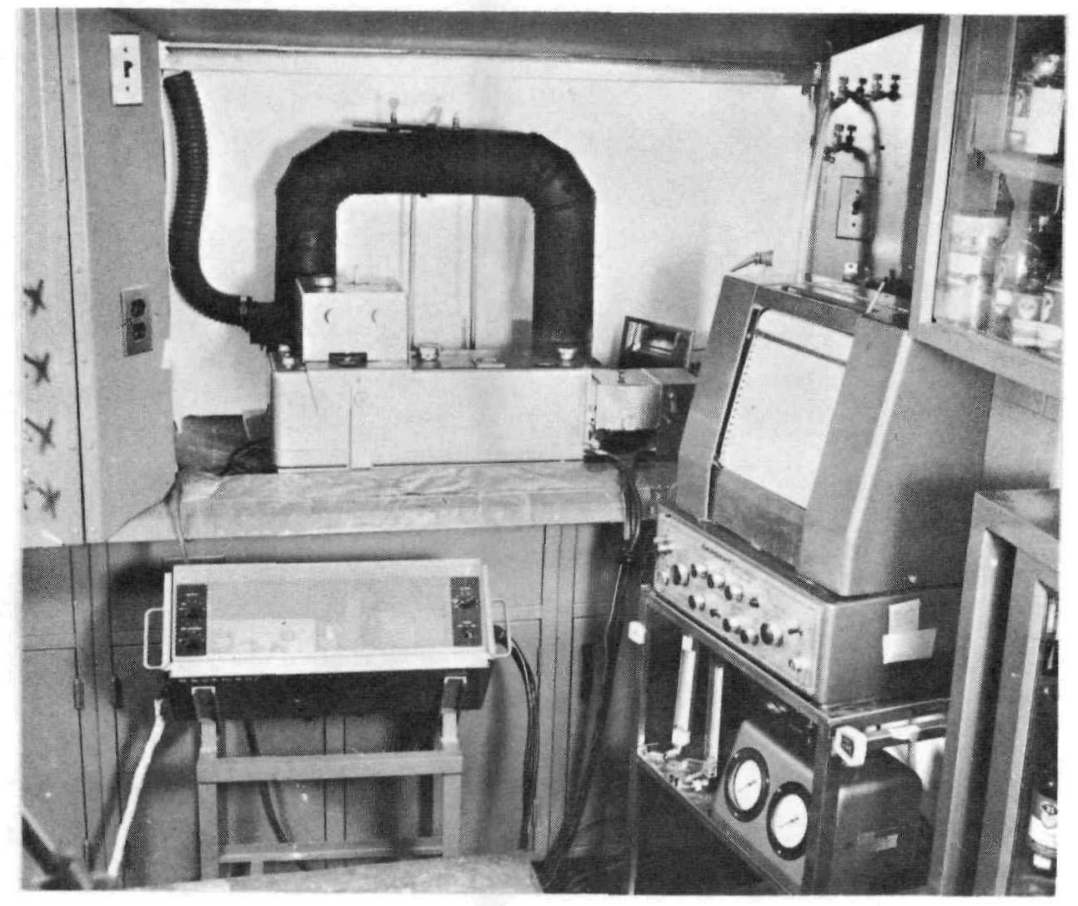

Figure 2.3

Recording Flame Spectrophotometer Installation 
Calibration data vere obtained for both strontiun and cesium in the presence of $40 \mathrm{mg} / \mathrm{ml}$ of uraniur. These data are presented in Tables 2.10 and 2.11. Over the strontium and cesium concentration ranges covered, 0 to $30 \mu \mathrm{g} / \mathrm{ml}$, there is a slight upward curvature caused by autorepression of ionization. Assuring linearity over the range, the standard deviation obtained was 0.10 for strontiurn and 0.07 for cesiura.

Table 2.10

Strontium Calibration Data (Flarie Photometry Determination)

Strontium

Concentration

$\frac{(c / m I)}{5}$

5

10

15

20

25

30
Response $\frac{(m v)}{2.78}$

2.78

6.08

9.22

12.70

16.23

19.75

frean $=1.617$

Standard Deviation $=0.10$
Factor

$(4 \mathrm{~s} / \mathrm{m}] / \mathrm{mv})$

1.798

1.644

1.627

1.575

1.540

1.518

Table 2.11

Cesiun Calibration Data

(Flame Photometry Deternination)

Cesium

Concentration

\section{$(4 \mathrm{~s} / \mathrm{m} 1)$}

5

10

15

20

25

30

\begin{tabular}{r}
$\begin{array}{c}\text { Response } \\
\text { (mv) }\end{array}$ \\
\hline 3.45 \\
7.48 \\
11.50 \\
15.45 \\
19.90 \\
23.93
\end{tabular}

Factor

(qg/mi/mv)

1.449

$1.33 ?$

1.304

1.294

1.256

1.254

lean $=1.315$

Standard Deviation $=0.07$

Variations of $\pm 20 \%$ in uranium concentration produced a negligible effect on response for both cases. 
The effects of various acid media were also investigated. The results for both strontiun and ceszun are presonted in Figures 2.4 and 2.5 . In the case of strontium, it is seen that the background is relatively high in both $\mathrm{HCI}$ and $\mathrm{HNO}_{3}$ but that this background is significantly reduced and that the emission line intensity is somewhat increased when $\mathrm{HCIO}_{4}$ is present in the sample medium. In the case of cesiur, perchloric acid does not have this pronounced effect. While several investigators have reported an enhancement of about $10 \%$ in the strontium line intensity in the presence of $\mathrm{HClO}_{4}$. the increased sensitivity observed here in the presence of uranium is due primarily to reduction in the uranium interference, i.eos reduction in the nonquantized radiation eritted by uranyl jons in oride fog or smoke. Similar suppressing of nonquantized radiation by $1 \mathrm{ICIO}_{4}$ has previously been observed in the presence of thorium.

In order to determine the optimum concentration of $\mathrm{HCIO}_{4}$ required, both cesium and strontiun were analyzed over a range of ${ }_{1010} \mathrm{O}_{4}$ concentrations. The results are presented in Figure 2.6. It is seen that the cesiun response is independent of $\mathrm{HClO}_{4}$ concentration, while the strontium response improves up to an IC104 concentration of 0.4 N. This was therefore taken to be the optimum concentration for analysis of these two components.

Interferences from various cations and anions vere also investigated under optimum perchloric acid conditions. The cation results are presented in Table 2.12; the anion results in Figure 2.7. It is seen that yttrium. zirconium, and molybdenum interfere with strontiun enission. While zirconium presents no problen in our application since it vill not be carried over in the dissolution steps, the yttriun and molybdenus interferences, if any, will be taken into account by the standard addition technique. The lanthanus interference vith cesiun is not expected to be troublesone since a relatively high concentration $(5 \mathrm{gm} / 25 \mathrm{mll}$ ) is required. Chloride and acetate anions produce little interference with strontium, however, sulfate decreases the response by about $50 \%$. Assesso ment of cation intererence was also carried out without using perchioric acid. These data showed that most of the rare earth elements interfered vith the strontium response at concentrations above $1 \mathrm{gm} / \mathrm{m}$.

From these investigations, it is concluded that interferences can be mininized or eliminated and thereby that $\mathrm{Sr}$ and $\mathrm{Cs}$ can be determined with a relative standard deviation of 5 and $6 \%$, resp., as indicated by the calibration data. 
Table 2.12

Assessment of Cation Interferences

(Sr and CS Determination by Flame Photometry)

\begin{tabular}{|c|c|c|c|}
\hline \multirow{2}{*}{ Cation } & \multirow{2}{*}{$\begin{array}{c}\text { Concentration } \\
(\mathrm{mg} / 25 \mathrm{mI})\end{array}$} & \multicolumn{2}{|c|}{ Percent Deviation } \\
\hline & & $\mathrm{Sr}(460.7 \mathrm{~m} /)$ & $\operatorname{cs}(852 \mathrm{~m} \mu)$ \\
\hline \multirow{3}{*}{ Yttriun } & 100 & 0 & 0 \\
\hline & 1,000 & +9.5 & 0 \\
\hline & 5,000 & +15.2 & 0 \\
\hline \multirow[t]{3}{*}{ Zirconium } & 100 & 0 & 0 \\
\hline & 1,000 & -14.2 & 0 \\
\hline & 5,000 & -14.5 & 0 \\
\hline \multirow[t]{3}{*}{ Rhodiun } & 100 & 0 & 0 \\
\hline & 1,000 & 0 & 0 \\
\hline & 5,000 & 0 & 0 \\
\hline \multirow[t]{3}{*}{ Palladiun } & 100 & 0 & 0 \\
\hline & 1,000 & 0 & 0 \\
\hline & 5,000 & 0 & 0 \\
\hline \multirow[t]{3}{*}{ Rutheniura } & 100 & 0 & 0 \\
\hline & 1,000 & 0 & 0 \\
\hline & 5.000 & 0 & 0 \\
\hline \multirow[t]{3}{*}{ Lanthanum } & 100 & 0 & 0 \\
\hline & 1.000 & 0 & 0 \\
\hline & 5,000 & 0 & -1.6 \\
\hline \multirow[t]{3}{*}{ Bariun } & 100 & 0 & 0 \\
\hline & 1,000 & 0 & 0 \\
\hline & 5,000 & 0 & 0 \\
\hline \multirow[t]{3}{*}{ Cadmium } & 100 & 0 & 0 \\
\hline & 1,000 & 0 & 0 \\
\hline & 5,000 & 0 & 0 \\
\hline \multirow[t]{3}{*}{ Cerơum } & 100 & 0 & 0 \\
\hline & 1,000 & 0 & 0 \\
\hline & 5,000 & 0 & 0 \\
\hline
\end{tabular}

(Continued) 
Table 2.12 (Continued)

Assessment of Cation Interferences

(Sr and CS Determination by Flame Photometry)

\begin{tabular}{|c|c|c|c|}
\hline \multirow{2}{*}{ Cation } & \multirow{2}{*}{$\begin{array}{c}\text { Concentration } \\
(\mathrm{mg} / 25 \mathrm{ml})\end{array}$} & \multicolumn{2}{|c|}{ Percent Deviation } \\
\hline & & $5 \mathrm{r}(460.7 \mathrm{m \mu})$ & $\mathrm{Cs}(852 \mathrm{~m}-\mathrm{s})$ \\
\hline \multirow[t]{3}{*}{ Praseodymium } & 100 & 0 & 0 \\
\hline & 1,000 & 0 & 0 \\
\hline & 5,000 & 0 & 0 \\
\hline \multirow[t]{3}{*}{ Neodymium } & 100 & 0 & 0 \\
\hline & 1,000 & 0 & 0 \\
\hline & 5,000 & 0 & 0 \\
\hline \multirow[t]{3}{*}{ Samarium } & 100 & 0 & 0 \\
\hline & 1,000 & 0 & 0 \\
\hline & 5,000 & 0 & 0 \\
\hline \multirow{3}{*}{ Europiun } & 100 & 0 & 0 \\
\hline & 500 & 0 & 0 \\
\hline & 1,000 & 0 & 0 \\
\hline \multirow[t]{3}{*}{ Gadolinium } & 100 & 0 & 0 \\
\hline & 500 & 0 & 0 \\
\hline & 1,000 & 0 & 0 \\
\hline \multirow[t]{3}{*}{ Molybdenum } & 100 & -15.0 & 0 \\
\hline & 1,000 & -29.2 & 0 \\
\hline & 5,000 & -21.7 & 0 \\
\hline \multirow[t]{3}{*}{ Indium } & 100 & 0 & 0 \\
\hline & 1,000 & 0 & 0 \\
\hline & 5,000 & 0 & 0 \\
\hline
\end{tabular}


THE EFFECT OF ACID MEDIA ON STRONTIUM EMISSION

IN THE PRESENCE OF URANIUM

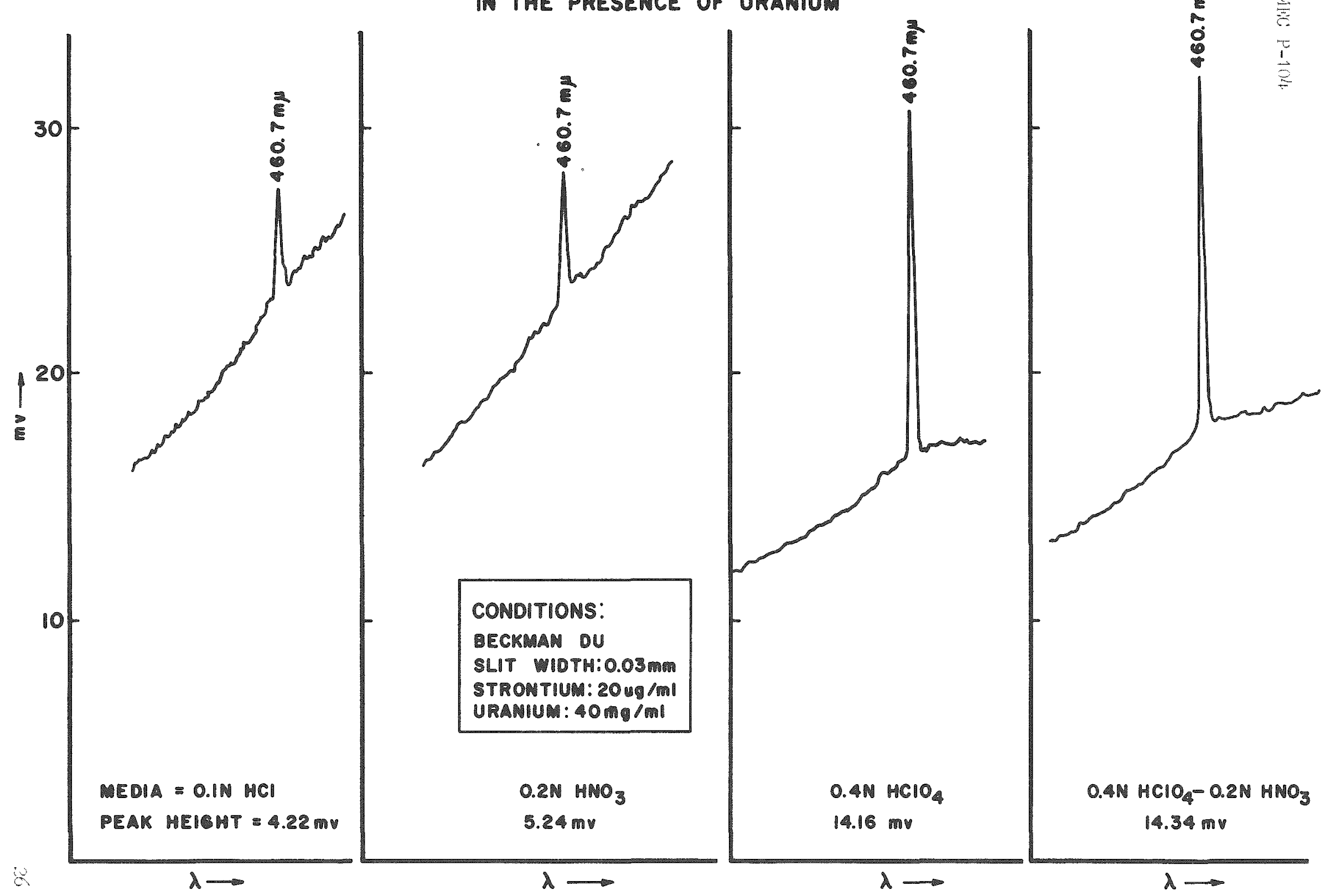


NUNEC P-1(N)

THE EFFECT OF ACID MEDIA ON CESIUM EMISSION

IN THE PRESENCE OF URANIUM

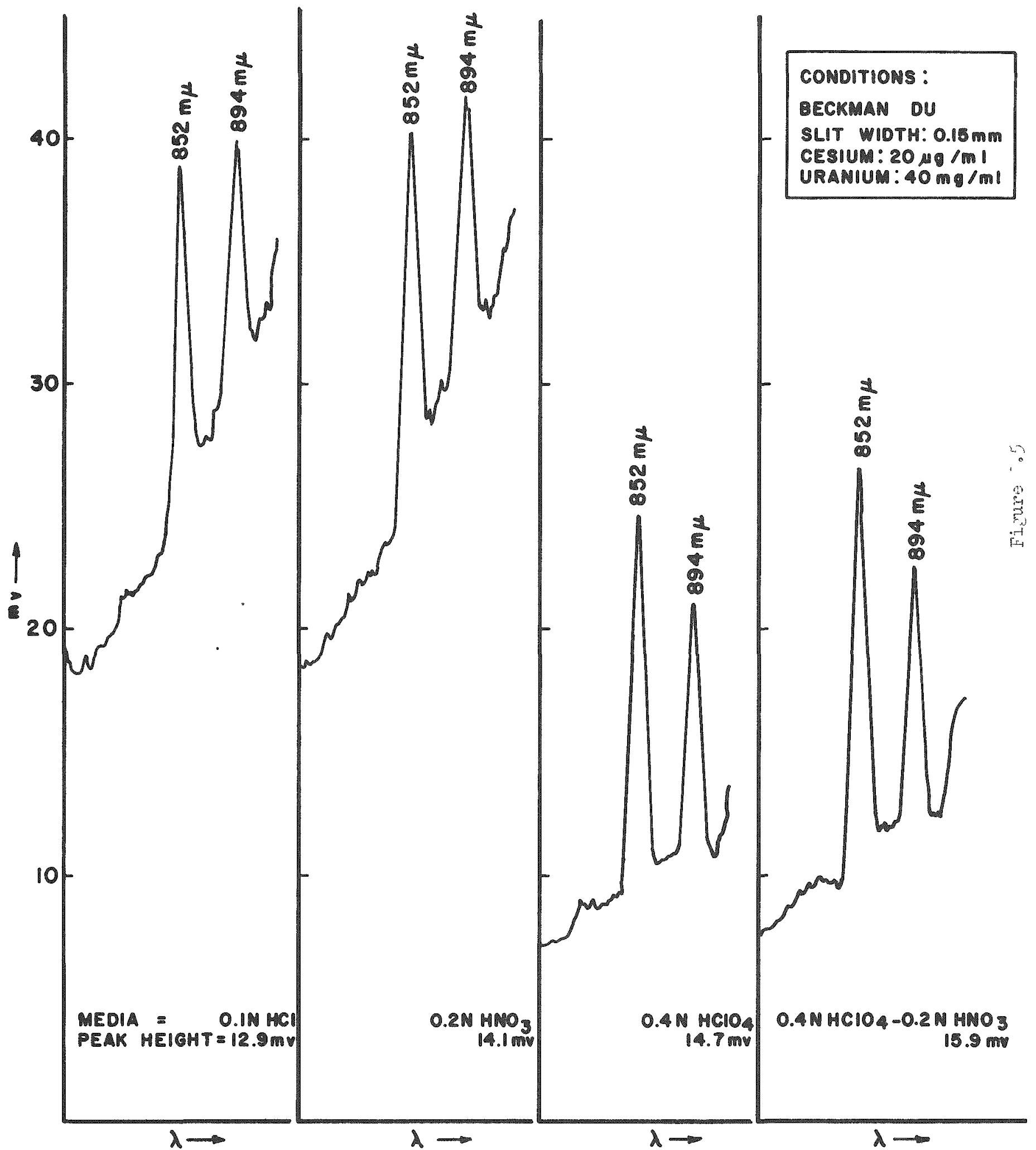




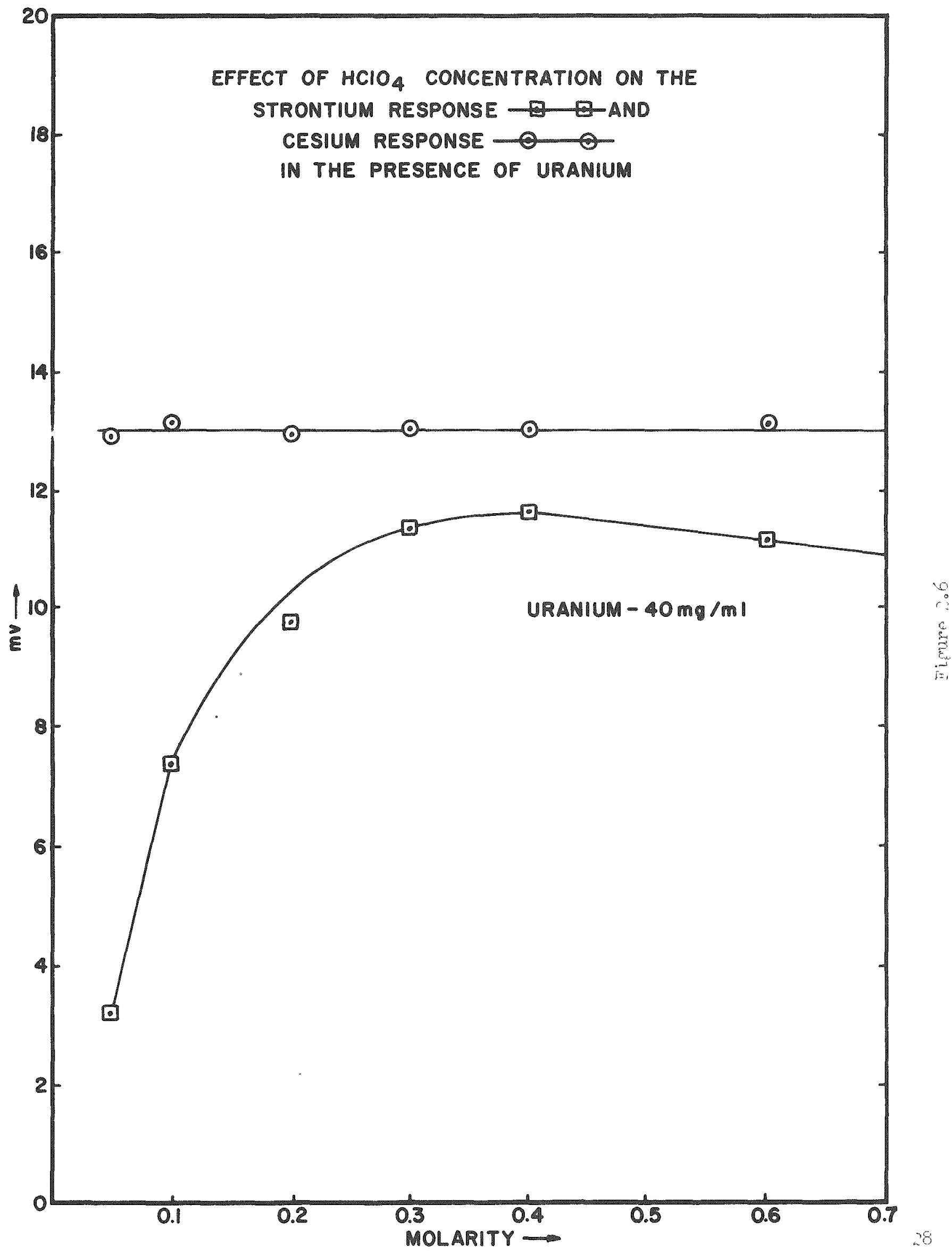




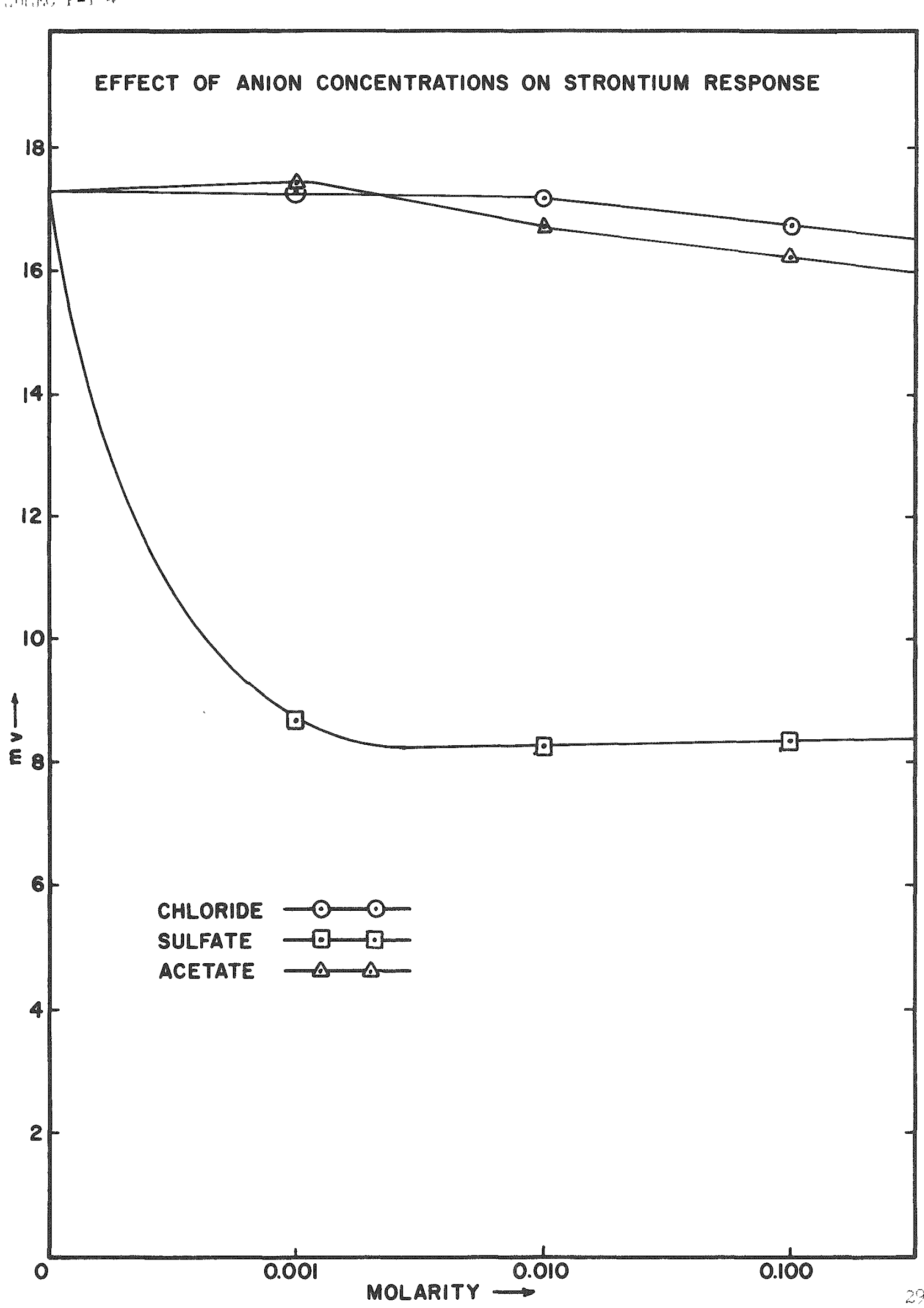


NUNEC P -104

\title{
FABRICATION AND EVALUATION OF FUEL SHAPES
}

\author{
Task 3.00 \\ E. Ko Halteman, Lo J. Jones, Io Do Thomas
}

${ }_{\text {PuO }} \frac{\text { Sintering Studies }}{\text { (M. Douston) }}$

Previously periormed sintering studies( 1 ) nith Puo 2 prepared by both the oxalate and hydroxide precipitation routes have yielded some, as yet unexplained, data. While attainment of high density has not been a problem, weight loss during sintering has been nore erratic, and microstructure variabiliby has been more pronounced than was anticipated based on the unifomity of the neasured physical characteristics of the starting powders. In particular, for some preparations, it was observed that the veight loss during air sintering was greater than observed during sintering in an $\mathrm{I}_{2}-6,3 \mathrm{H}_{2}$ reducing atmosphere. This is contrary to the anticipated result since $\mathrm{PuO}_{2}$ tends to reduce to $\mathrm{Pu}_{2} \mathrm{O}_{3}$. It appears that these erratic results may be due to sintering atmosphere impurities, $i_{\text {. }}$. oxygen or moisture in the reducing atnosphere, or to residual carbon content in the $\mathrm{PuO}_{2}$. During this reporting period, the effects of carbon addition have been investigated.

For these studies oxalate derived $\mathrm{PuO}_{2}$ was utilized; the calcination temperature was $1100^{\circ} \mathrm{C}$. Samples containing 1,2, and $5 \mathrm{w} / 0$ carbon were prepared by mixing the powders in a mortar as a damp slush containing alcohol.

Powder samples, including those containing no carbon additions, were exposed to the $\mathrm{N}_{2}-6 \% \mathrm{H}_{2}$ sintering atnosphere for various periods of time, and following observation of weight changes, they were then ignited in flowing orygen at $1100^{\circ} \mathrm{C}$ and reweighed.

For reference, it is pointed out that complete reduction of $\mathrm{PuO}_{2}$ to $\mathrm{Pu}_{2} \mathrm{O}_{3}$ constitutes a loss of oxygen amounting to $2.95 \%$ of the initial weight of $\mathrm{PuO}_{2}$. Weight losses for carbon free materials up to this naximum are therefore anticipated and reversible weight gains on oxidation are also to be expected. The neasured results on $\mathrm{PuO}_{2}$ without carbon addition are presented in Table 3.1. It is seen that these data are erratic. While most samples lost weight during reduction and gained weight during oxidation. only a few samples gave indication that these processes are reversible. It is quite obvious that further experinentation is warranted with stricter control of all parameters, especially atmosphere purity control.

(i) HULEC P-90, P-100, P-101, P-102, P-103, Progress Reports, Eevelopment of Plutonium-Bearing Fuel Materials" 
Table 3.1

Reduction-0xidation Data for $\mathrm{PuO}_{2}$

Reduced at $1600^{\circ} \mathrm{C}$ in $\mathrm{H}_{2}-6 \% \mathrm{I}_{2}$

oxidized at $1100^{\circ} \mathrm{C}$ in $\mathrm{O}_{2}$

\begin{tabular}{|c|c|c|c|}
\hline $\begin{array}{l}\text { Sample } \\
\text { Number }\end{array}$ & $\begin{array}{c}\text { Reduction } \\
\text { Time } \\
\text { hours } \\
\end{array}$ & $\begin{array}{c}\text { Weight Loss } \\
\text { on Reduction } \\
g\end{array}$ & $\begin{array}{c}\text { Weight Gain } \\
\text { on Oxidation } \\
g\end{array}$ \\
\hline 1 & 1 & -0.05 & 0.10 \\
\hline 2 & 1 & -0.20 & -0.13 \\
\hline 3 & 16 & $a 00.11$ & 0.22 \\
\hline 4 & 1 & 0.72 & 0.85 \\
\hline 5 & 1 & 0.80 & 0.83 \\
\hline 6 & 1 & 1.60 & 0.76 \\
\hline 7 & 1 & 0.72 & 0.41 \\
\hline 8 & 16 & 1.40 & 0.31 \\
\hline 9 & 16 & 4.20 & -1.30 \\
\hline 10 & 16 & 3.50 & 0.24 \\
\hline 11 & 16 & 2.20 & 0.11 \\
\hline 12 & 40 & -0.10 & 0.63 \\
\hline 13 & 40 & -0.18 & 0.51 \\
\hline 14 & 40 & 0.02 & 0.17 \\
\hline 15 & 70 & $=0.40$ & 0.39 \\
\hline 16 & 70 & -0.30 & 0.30 \\
\hline $1 ?$ & 70 & 0.10 & 0.21 \\
\hline 18 & 70 & -0.25 & 0.28 \\
\hline 19 & 17 & 0.05 & - \\
\hline 20 & 17 & 0.11 & - \\
\hline 21 & 17 & 0.25 & - \\
\hline 22 & 17 & 0.25 & - \\
\hline
\end{tabular}


For the samples containing carbon additions, the results are presented in Table 3.2. It is pounted out that $18 \mathrm{PuO}_{2}$ vere to contain $2.2 \mathrm{~m} / \mathrm{O}$ carbon it can be entirely reduced to $\mathrm{Pu}_{2} \mathrm{O}_{3}$ with the concomitant release of $\mathrm{CO}$; the total weight loss on reduction under these conditions would be $5.05 \%$ of the initial sariple weight. The data show an initial high veight loss and subsequent weight increase with time, with the net veight loss appearing to approach the anount of the carbon addition. These results strongly sugcest that the $\mathrm{N}_{2}-6, \mathrm{H}_{2}$ atrosphere contains sufficient noisture to cause reoxudation of $\mathrm{Pu}_{2} \mathrm{O}_{3}$ to $\mathrm{PuO}_{2}$ during the extended reduction cycles.

\section{lixed Oxide Sintering Studies (1:. D. Ilouston)}

Sintering trials on coprecipitated $\mathrm{UO}_{2}-\mathrm{PuO}_{2}$ have been continued. During this reporting period, pellets were fabricated from two batches of $\mathrm{UO}_{2-12.5} \mathrm{~m} / \mathrm{O} \mathrm{PuO}_{2}$ and 2 batch of $\mathrm{UO}_{2}-35 \mathrm{k} / \mathrm{O} \mathrm{PuO}_{2}$ 。

The two batches of $\mathrm{UO}_{2}-12.5 \mathrm{w}_{\mathrm{O}} \mathrm{PuO}_{2}$ utilized vere processed by the "standard" coprecipitation procedure except that batch 297pu20 was precipitated with 14.5 I amonia wijle for batch $297 \mathrm{Pu} 24,3.5$ Ii amonia was used. As reported previously, (I) the powder characteristics were not appreciably influcnced by this change in ammia concentration.

The results of the sintering trials are presented in Table 3.3. It is seen that for both batches of material (except for lot Pu24-550 740 which was essentially unconverted, o/li ratio of 2.66) the sintered densities ranged between 93.5 and $97.2 \%$ of theorctical.

$\mathrm{UO}_{2}-35 \mathrm{w} / \mathrm{O} \mathrm{PuO}_{2}$ pellets uere also sintered for 1,16 , and 24 hours in an $\mathrm{H}_{2}-6.6 \mathrm{H}_{2}$ atwosphere in order to further investigate the reasons for the previously obtained low densities. lletallographic examination of these compacts, as show in Figure 3.1, shows grain growth and broadening of grain boundaries with sintering time. Presumably this latter phenonenon is due to formation of a second phase which is anticipated in high plutonia content compacts in the presence of a reducing atmosphere. $X-r a y$ diffraction vill be utilized to identify this phase, if a sufficient amount is presento

\section{Production of Spherzcal Particles by Plasia Torch} (T. M. Benson)

Further trial runs have been made to produce high density $\mathrm{VO}_{2}-20 \mathrm{v} / \mathrm{O} \mathrm{PuO}_{2}$ spheres using the F-40 Thermal Dynames plasma torch. over the complete

(i) NUWC P-103, Progress Report, "Development of Plutoniur-Bearing Fuel İaterials" page 18 . 
NUNTC $P-104$

Table 3.2

Reduction Data for $\mathrm{PuO}_{2}+\mathrm{C}$ Reduced at $1600^{\circ} \mathrm{C}$ in $\mathrm{N}_{2}-66^{\circ} \mathrm{II}_{2}$

\begin{tabular}{|c|c|c|}
\hline Composition & $\begin{array}{c}\text { Reduction } \\
\text { Time } \\
\text { hours }\end{array}$ & $\begin{array}{c}\text { Weight Loss } \\
\text { Puo } 2^{-2} \mathrm{w} / 0 \mathrm{C}\end{array}$ \\
\hline & 1 & 3.4 \\
& 4 & 2.8 \\
& 16 & 2.6 \\
$\mathrm{PuO}_{2}-5 \mathrm{w} / \mathrm{C}$ & 1 & 8.2 \\
& 4 & 7.3 \\
& 16 & 5.9 \\
& 18 & 5.3 \\
\hline
\end{tabular}


Table 3.3

Sintering Data

for Coprecipitated $\mathrm{VO}_{2}-12.5 \% \mathrm{PuO}_{2}$

(Sintered at $1600^{\circ} \mathrm{C}$ in $\mathrm{N}_{2}-6, \mathrm{H}_{2}$ )

\begin{tabular}{|c|c|c|c|c|c|c|}
\hline Composition & $\begin{array}{c}\text { Compaction } \\
\text { Pressure } \\
\text { TSI } \\
\end{array}$ & $\begin{array}{c}\text { Green } \\
\text { Density } \\
\text { gry } / \mathrm{cc} \\
\end{array}$ & $\begin{array}{c}\text { Linear } \\
\text { Shrinase } \\
3 \\
\end{array}$ & $\begin{array}{c}\text { Weight Loss } \\
\text { on Firing } \\
p^{3}\end{array}$ & $\begin{array}{l}\text { Tired } \\
\text { Density } \\
\end{array}$ & $\begin{array}{c}\text { Percent } \\
\text { Theoretical } \\
\text { Density } \\
\end{array}$ \\
\hline Pu20-1580-740* & $\begin{array}{l}10 \\
20\end{array}$ & $\begin{array}{l}5.04 \\
5.65\end{array}$ & $\begin{array}{l}21.0 \\
19.0\end{array}$ & $\begin{array}{l}1.4 \\
1.4\end{array}$ & $\begin{array}{l}10.45 \\
10.54\end{array}$ & $\begin{array}{l}94.5 \\
95.5\end{array}$ \\
\hline Pu20-5580-640 & $\begin{array}{l}10 \\
20\end{array}$ & $\begin{array}{l}4.68 \\
5.40\end{array}$ & $\begin{array}{l}23.0 \\
20.0\end{array}$ & $\begin{array}{l}2.1 \\
2.0\end{array}$ & $\begin{array}{l}10.37 \\
10.43\end{array}$ & $\begin{array}{l}93.7 \\
94.5\end{array}$ \\
\hline Pu20-5580-740 & $\begin{array}{l}10 \\
20\end{array}$ & $\begin{array}{l}5.01 \\
5.67\end{array}$ & $\begin{array}{l}22.0 \\
19.0\end{array}$ & $\begin{array}{l}1.4 \\
1.4\end{array}$ & $\begin{array}{l}10.51 \\
10.57\end{array}$ & $\begin{array}{l}95.1 \\
95.6\end{array}$ \\
\hline Pu20-SS160-740 & $\begin{array}{l}10 \\
20\end{array}$ & $\begin{array}{l}5.10 \\
5.74\end{array}$ & $\begin{array}{l}22.0 \\
19.0\end{array}$ & $\begin{array}{l}1.3 \\
1.3\end{array}$ & $\begin{array}{l}10.44 \\
10.55\end{array}$ & $\begin{array}{l}94.5 \\
95.5\end{array}$ \\
\hline Pu20-5S80-840 & $\begin{array}{l}10 \\
20\end{array}$ & $\begin{array}{l}5.28 \\
5.90\end{array}$ & $\begin{array}{l}22.0 \\
18.0\end{array}$ & $\begin{array}{l}1.2 \\
1.3\end{array}$ & $\begin{array}{l}10.57 \\
10.59\end{array}$ & $\begin{array}{l}95.6 \\
95.7\end{array}$ \\
\hline Pu20-RS80-740* & $\begin{array}{l}10 \\
20\end{array}$ & $\begin{array}{l}4.97 \\
5.70\end{array}$ & $\begin{array}{l}23.0 \\
19.0\end{array}$ & $\begin{array}{l}2.0 \\
2.0\end{array}$ & $\begin{array}{l}10.46 \\
10.44\end{array}$ & $\begin{array}{l}94.6 \\
94.5\end{array}$ \\
\hline Pu24-TS80-740 & $\begin{array}{l}10 \\
20\end{array}$ & $\begin{array}{l}5.08 \\
5.80\end{array}$ & $\begin{array}{l}22.0 \\
18.0\end{array}$ & $\begin{array}{l}1.7 \\
1.7\end{array}$ & $\begin{array}{l}10.71 \\
10.55\end{array}$ & $\begin{array}{l}96.9 \\
95.5\end{array}$ \\
\hline Pu24-SS80-640 & $\begin{array}{l}10 \\
20\end{array}$ & $\begin{array}{l}4.71 \\
5.50\end{array}$ & $\begin{array}{l}23.0 \\
19.0\end{array}$ & $\begin{array}{l}2.4 \\
2.4\end{array}$ & $\begin{array}{l}10.34 \\
10.37\end{array}$ & $\begin{array}{l}93.6 \\
93.7\end{array}$ \\
\hline$P u 24-550-740$ & $\begin{array}{l}10 \\
20\end{array}$ & $\begin{array}{l}4.14 \\
4.87\end{array}$ & - & $\begin{array}{l}3.8 \\
4.2\end{array}$ & $\begin{array}{l}\text { Fracture } \\
\text { Fracture }\end{array}$ & - \\
\hline Pu24-5S80-740 & $\begin{array}{l}10 \\
20\end{array}$ & $\begin{array}{l}4.99 \\
5.71\end{array}$ & $\begin{array}{l}22.0 \\
18.0\end{array}$ & $\begin{array}{l}1.6 \\
1.6\end{array}$ & $\begin{array}{l}10.56 \\
10.49\end{array}$ & $\begin{array}{l}95.6 \\
94.9\end{array}$ \\
\hline Pu24-SS120-740 & $\begin{array}{l}10 \\
20\end{array}$ & $\begin{array}{l}5.10 \\
5.74\end{array}$ & $\begin{array}{l}22.0 \\
19.0\end{array}$ & $\begin{array}{l}1.8 \\
1.8\end{array}$ & $\begin{array}{l}10.58 \\
10.72\end{array}$ & $\begin{array}{l}95.7 \\
97.0\end{array}$ \\
\hline Pu24-S5160-740 & $\begin{array}{l}10 \\
20\end{array}$ & $\begin{array}{l}5.12 \\
5.82\end{array}$ & $\begin{array}{l}22.0 \\
18.0\end{array}$ & $\begin{array}{l}1.6 \\
1.7\end{array}$ & $\begin{array}{l}10.56 \\
10.51\end{array}$ & $\begin{array}{l}95.6 \\
95.1\end{array}$ \\
\hline Pu24-3580-840 & $\begin{array}{l}10 \\
20\end{array}$ & $\begin{array}{l}5.47 \\
6.06\end{array}$ & $\begin{array}{l}20.0 \\
18.0\end{array}$ & $\begin{array}{l}1.2 \\
1.3\end{array}$ & $\begin{array}{l}10.55 \\
10.75\end{array}$ & $\begin{array}{l}96.4 \\
97.2\end{array}$ \\
\hline Pu24-RS80-740 & $\begin{array}{l}10 \\
20\end{array}$ & $\begin{array}{l}5.04 \\
5.76\end{array}$ & $\begin{array}{l}21.9 \\
18.2\end{array}$ & $\begin{array}{l}2.1 \\
2.1\end{array}$ & $\begin{array}{l}10.53 \\
10.45\end{array}$ & $\begin{array}{l}95.4 \\
94.5\end{array}$ \\
\hline
\end{tabular}

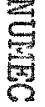

* Non-milled 


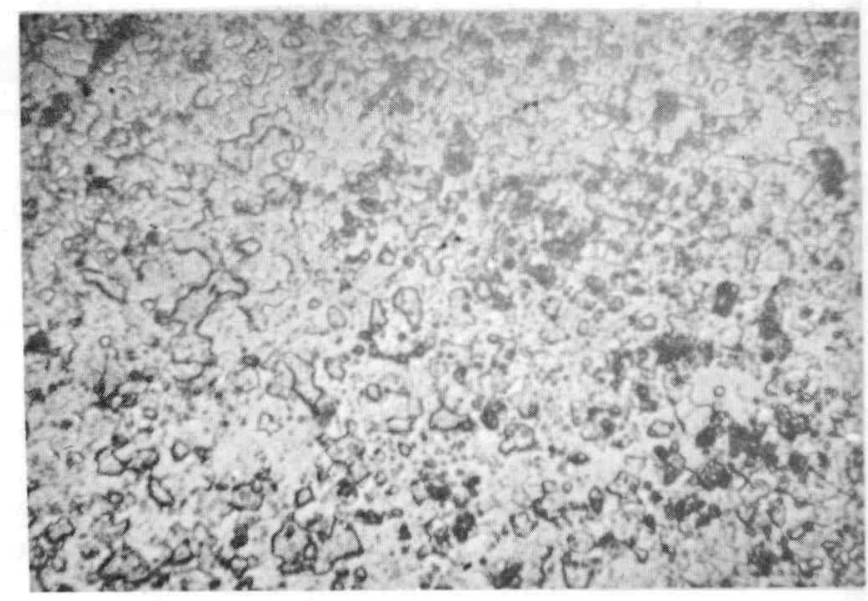

Sintering Time - 1 hour Neg. 450

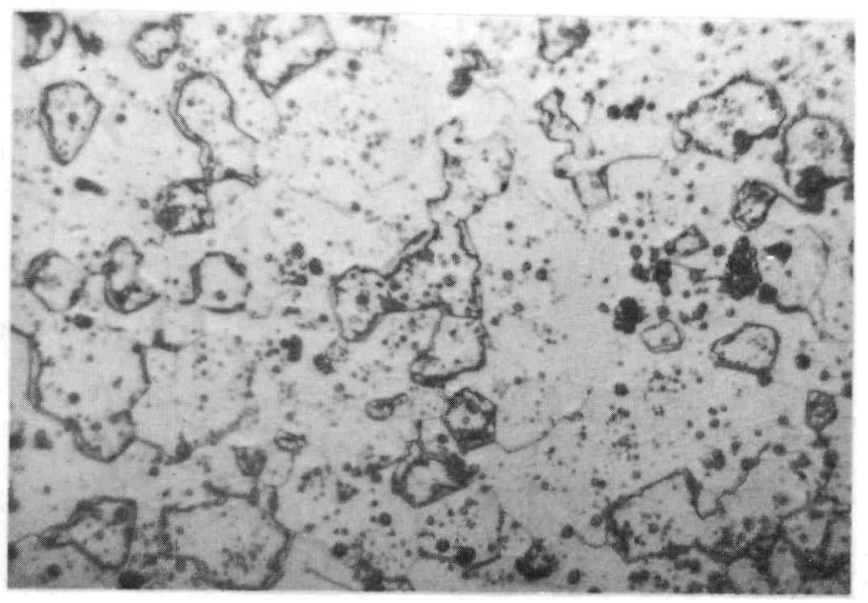

Sintering Time - 16 hours

400X Neg. 459
$400 \mathrm{X}$

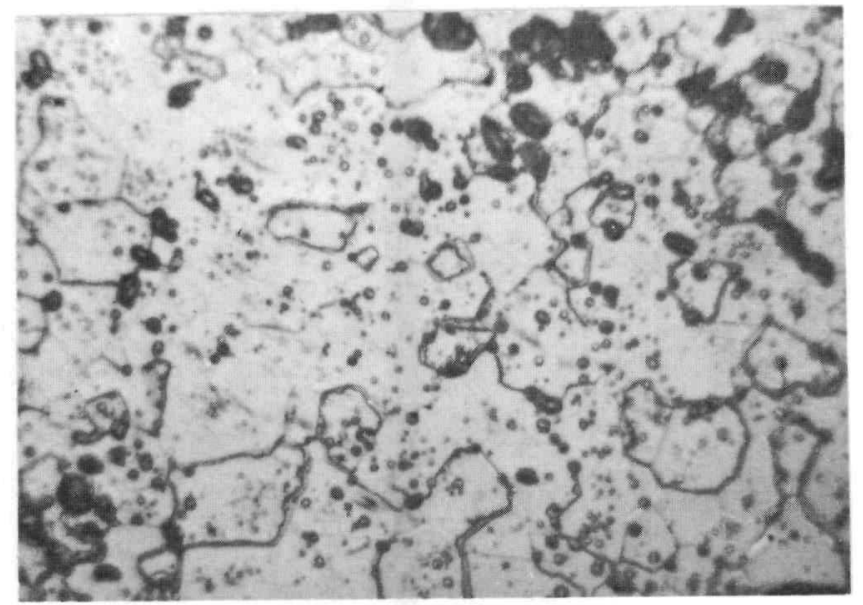

Sintering Time - 24 hours Neg. 452 $400 \mathrm{x}$

Figure 3.1

Photomicrographs of $\mathrm{UO}_{2}-35 \% \quad \mathrm{PuO}_{2}$

Compaction Pressure - 11.? TSI

Sintered in $\mathrm{N}_{2}-6 \% \mathrm{H}_{2}$ at $1600^{\circ} \mathrm{C}$ 
range of torch conditions and gas compositions and flow rates, no better material has been produced than that described previously. (i) Torch modifications are now being designed to improve the particle residence time within the flame.

\section{Production of Spherical Particles by Agglomeration (C. S. Caldwel1)}

For dispersion-type fuel elements, spherical particles having high crushing strength are required in order to minimize particle breakage and deformation during subsequent fabrication processes. Since it may not be possible to produce such high strength particles by plasma torch fusion, an investigation has been initiated to form spherical particles of $\mathrm{PuO}_{2}$ by agglomeration.

For these initial studies, $\mathrm{PuO}_{2}$ agglomerates were formed in a small mill jar, and the particle size distribution of both formable and non-formable powder fractions were determined by centrifugal sedimentation size analysis; B.E.T. surface areas were also determined. 297pug-Lot 4 material produced by "standard" oxalate precipitation was used as feed.

The results indicate that the finer particles in the powder are selectively "snowballed" into spherical shape, thereby leaving behind a residue of course particles. The surface areas of the particles in the formed particulates, however, were not significantly different from the surface areas of the particles in the residues. The particle size distributions for particles in the green spheres are compared to the size distributions of particles in the residues in Figures 3.2-3.4. For two of the samples, $B_{1}$ and $P_{3}$, further rolling of the residues after sphere removal resulted. in no further yield of spheres: for Sample B-3-15, such additional treatment yielded aggloneration of 8,3 of the residual powder into +120 mesh particles, however, these particles had extremely poor green strength. These results indicate that sphere forming efficiency is dependent upon the particle size distribution of the feed powders. strict control of feed particle size is therefore required this can be attained to some degree by the control of pouder preparation variables, however, various milling procedures must also be evaluated.

$$
\frac{\text { Oxidation Kinetics of } \mathrm{VO}_{2}-\mathrm{PuO}_{2}}{\left(\mathrm{R}_{0}\right. \text { Gerrish) }}
$$

To aid in the interpretation of sintering data as vell as to assess the effects of oridizing environments, a program has been initiated to determine the oxidation kinetics of $\mathrm{UO}_{2}-\mathrm{PuO}_{2}$ by means of themogravimetric analysis.

(i) NUHC P 103. Progress Report, "Development of Plutonium-Bearing Fuel liaterials" page 29. 


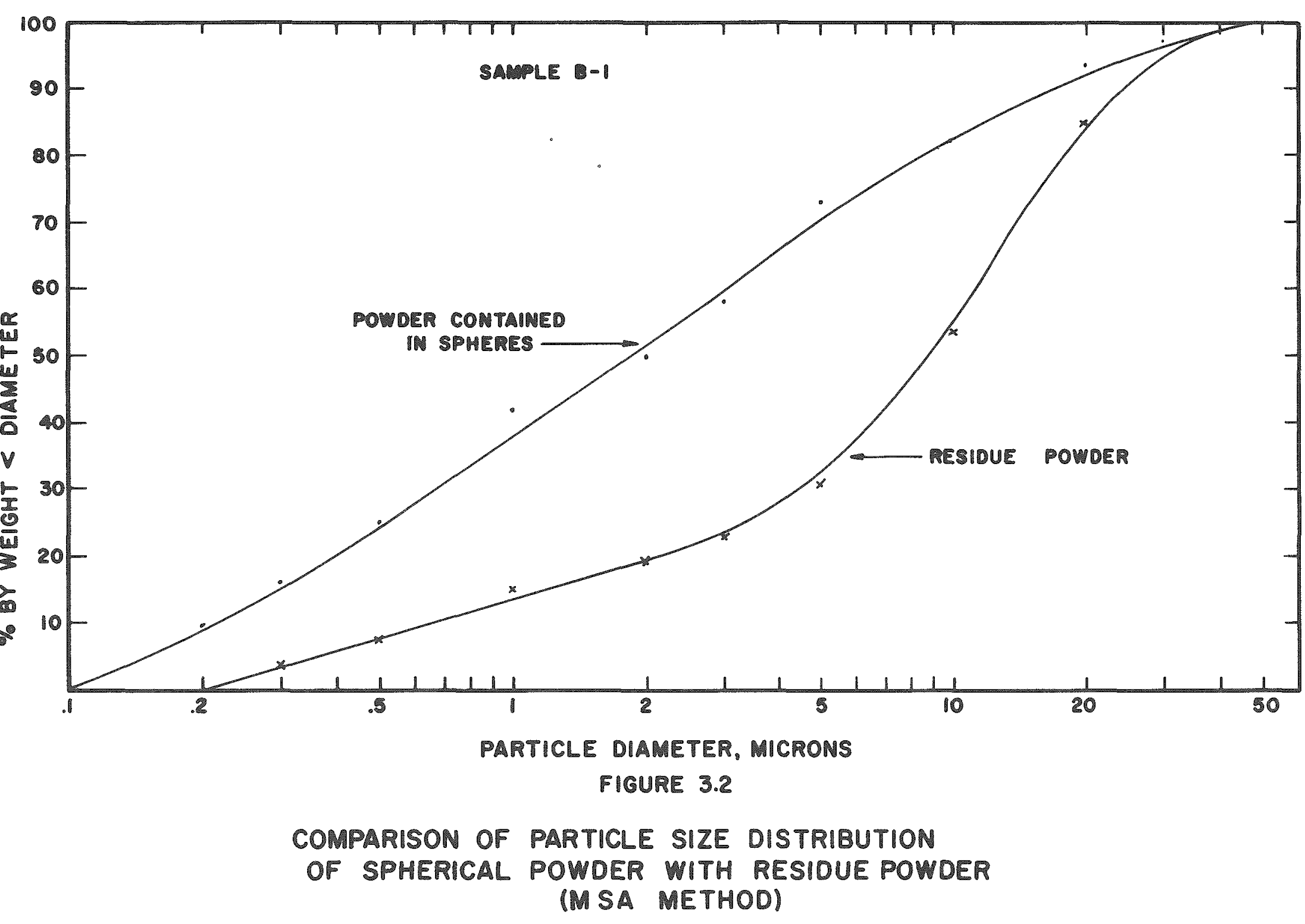




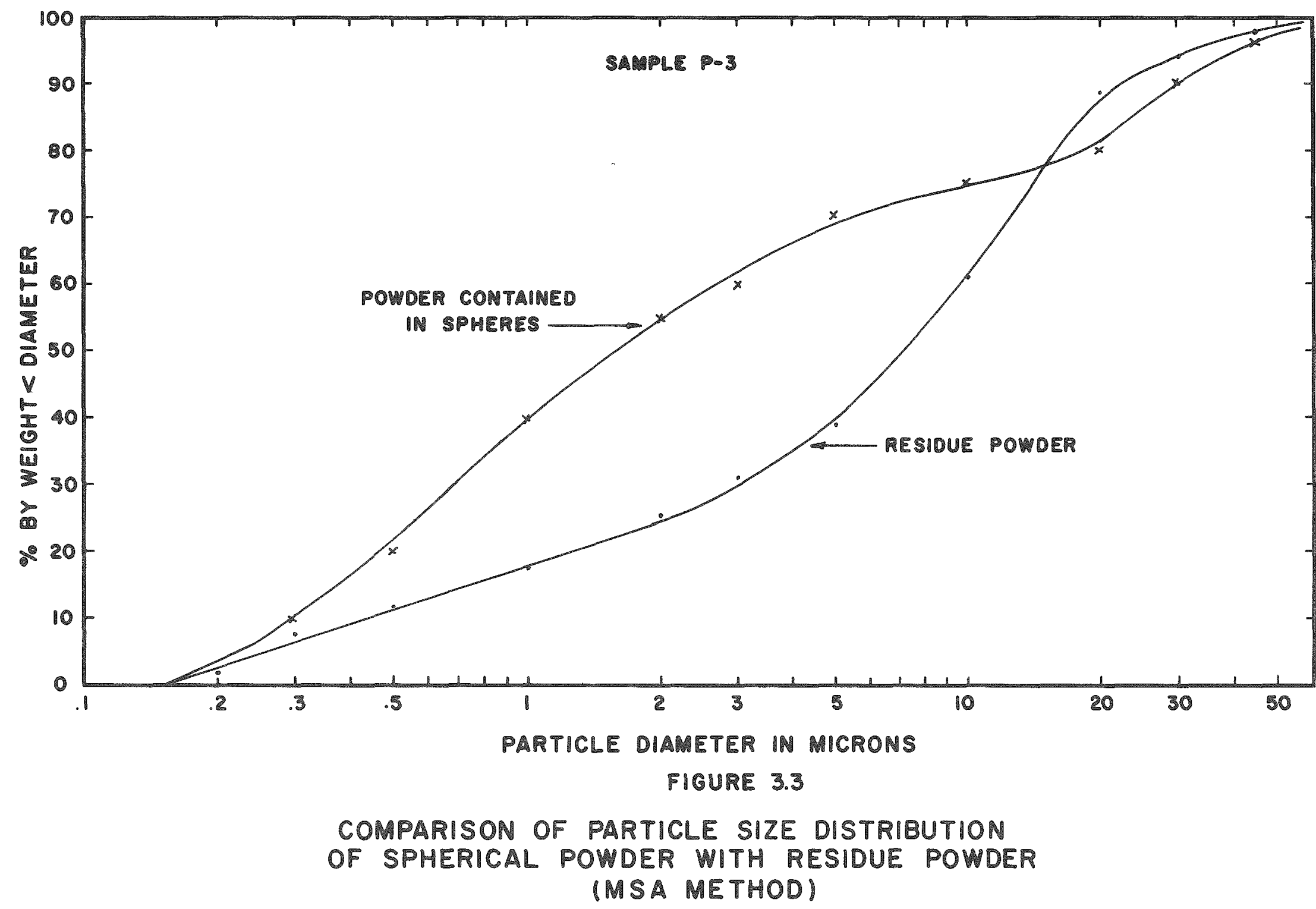




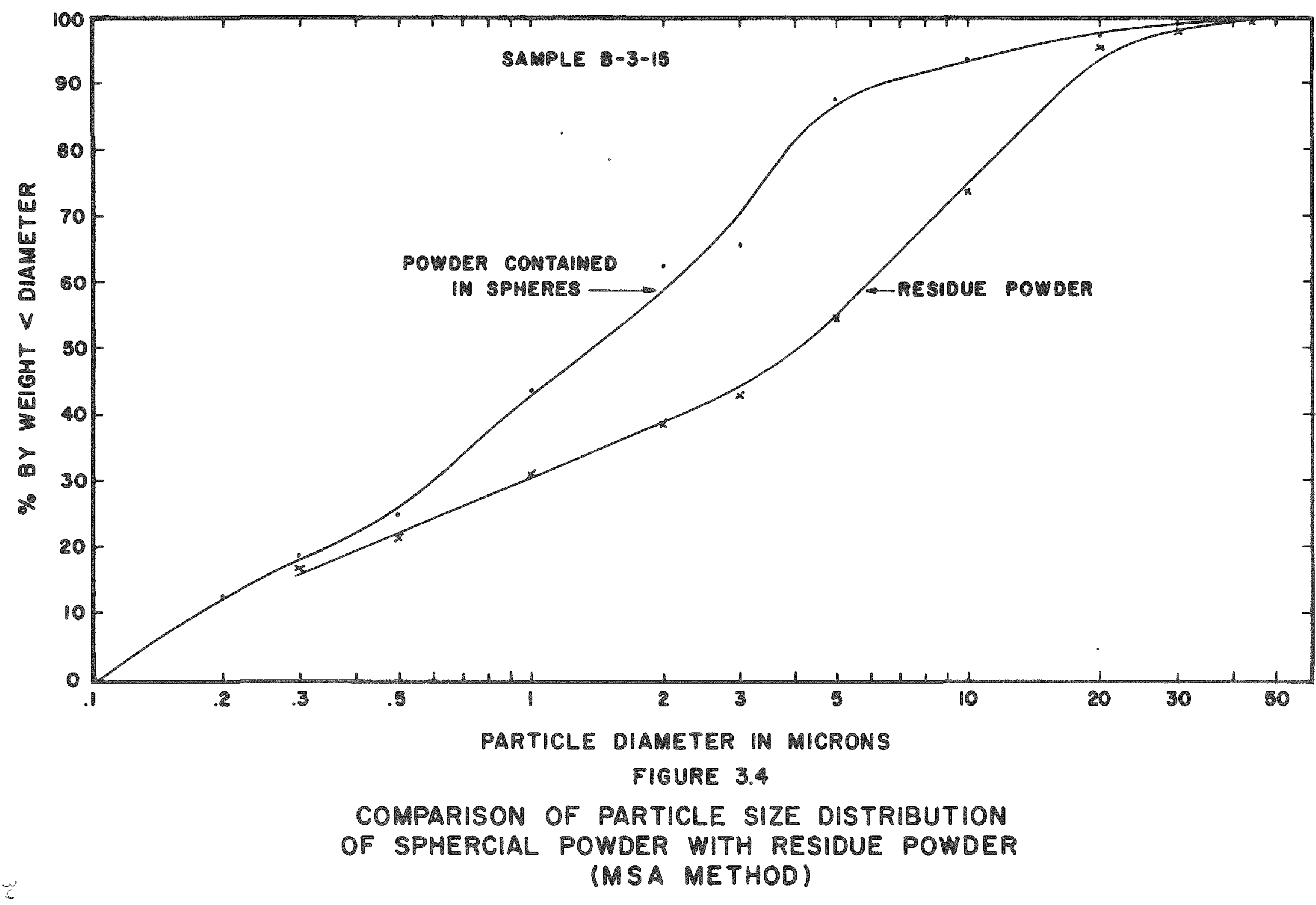


As a prelininary, the glove box procedures involved in the use of the thermogravimetric balance were evaluated by oxidizing characterized $\mathrm{VO}_{2}$ powdex to $\mathrm{U}_{3} \mathrm{O}$. These kinetic data vere then used to determine the diffusion coefficient of oxygen in $\mathrm{UO}_{2}$ using a prograrn written for the RPG-4000 computer. The result of a least squares fit to an Arrhenius plot for values of the diffusion coefficient against $1 / \mathrm{T}$ indicated that in the temperature range of 200 to $300^{\circ} \mathrm{C}$ the diffusion of oxysen in urania can be represented by the equation

$$
D=1.1 \times 10^{-2} \exp (-27,100 / R T) \mathrm{cm}^{2} / \mathrm{sec}
$$

Over the measured temperature range, this result agrees well with that obtained by Aronson, et al ${ }^{(1)}$, who represented their data by the equation

$$
\mathrm{D}=5.5 \times 10^{-3} \exp (\infty 26,300 \pm 1500 / \mathrm{RT}) \mathrm{cm}^{2} / \mathrm{sec}
$$

Prelininary oxidation runs using $\mathrm{VO}_{2} \mathrm{FuO}_{2}$ sintered pellets indicate a considerable reduction in the oxidation rate. The observed diffusion coefficient is 3 to 4 orders of magnitude smaller than for pure urania. due mainly to the use of sintered pellets and to the dilution of the cations with plutonium which is in its highest state of oxidation. The pellets used in these initial oxidation kinetic studies were prepared from batch $297 \mathrm{Pu} 4 \mathrm{material}$ having a composition of $\mathrm{vO}_{2}-5 \mathrm{w} / \mathrm{O} \mathrm{PuO}_{2}$.

\section{Physical Property lleasurements}

$$
\text { (E。 Ko Halteman, R。Gerrish, JoRoth) }
$$

In preparation for glove box close-up, all nodifications to the thermal conductivity apparatus have been completed, and the equipment is again operating. Samples of $\mathrm{Al}_{2} \mathrm{O}_{3}$ and $\mathrm{lg} g \mathrm{O}$ have been fabricated, and their theral conductivities will be determined as a final check on the equipment prior to comitnent to plutonium.

The stepless programed temperature controller for the high temperature dilatometer has been modified to give better impedance matching to the Low resistance heating element. In addition, current liniters are being incorporated in the unit by the manufacturer. The tungsten/tungsten $-26 ;$ rheniur thermocouple used to provide the input to the temperature controller has been calibrated by using the freezing points of pure metals as standard temperature points. Quartz supports and pusher rods have also been procured in order to increase the sensitivity of the dilatometer in the low temperature range below $1000^{\circ} \mathrm{C}$.

(i) S. Aronson, R. Roof, Jro, and J. Belle, J. Chem. Phys., 27, $137(1957)$. 
The installation of an IRC high temperature $x$-ray camera on a diffractometer has been completed. The glove box with all the necessary electrical lead-throughs has been installed and made leak-tight. The diffractometer has been aligned, and preliminary runs have been made using reduced $\mathrm{UO}_{2}$. The lattice parameters were calculated using standard procedures, i.e." Nelson and Riley extrapolation to $\sigma=0$, using a progran written for the RPC-4000 computer. This equipment is now ready for cormitment to plutonium. 
NUWEC $P-104$

FUEL ELEMENT FABRICATION AND EVALUATION

\author{
Task 4.00 \\ L。 Jo Jones Io Do Thomas \\ Compatibility study \\ (M. Zambernard)
}

Preparation of duplex pellets for determining reaction between $\mathrm{UO}_{2}-\mathrm{PuO}_{2}$ of various compositions and possible cladding and diluent metals is continuing. Netallography and $x$-ray diffraction examination of samples containing $\mathrm{PuO}_{2} / \mathrm{UO}_{2}$ ratios of $0.5,5,12.5,17.8$, and $35 \mathrm{w} / 0 \mathrm{PuO}_{2}$ and the metals, 304 and 316 stainless, iron, nickel and chromium have been initiated. These data will be presented in the next progress report.

\title{
Corrosion Tests \\ (M. Zambernard)
}

Pellets of pure $\mathrm{PuO}_{2}$ and six compositions of coprecipitated $\mathrm{UO}_{2}-\mathrm{PuO}_{2}$ have been fabricated to allow initiation of corrosion tests in $650^{\circ}$ F vater and $750^{\circ} \mathrm{F}$ steam. $\mathrm{All}$ pellets vere sintered in an $\mathrm{N}_{2}-6, \mathrm{H}$. phere for one hour at $1600^{\circ} \mathrm{F}$. The ranges of densities attained are shown in Table 4.1. The $\mathrm{UO}_{2}-80 \mathrm{w} / 0 \mathrm{PuO}_{2}$ pellet densities were low, hence, these were refired for 16 hours at $1600^{\circ} \mathrm{C}$, hovever, the increase in density was only approximately 1.5\%. Indication of poor sinterability of this material was given by the extraordinarily high $\left(6.8 \mathrm{gm} / \mathrm{cm}^{3}\right)$ tap density of the starting powder.

All pellets, including the $\mathrm{UO}_{2}{ }^{\mathrm{m}} 80 \mathrm{v} / \mathrm{O} \mathrm{PuO}_{2}$ composition, will be corrosion tested. For the low density pellets it will be difficult to determine the actual area in contact with the corrosive media; however, if there is little or no attack (as expected), the results will, nevertheless, provide positive information.

As a preliminary to the extended time corrosion test, i.e., 100, 500, and 1000 hours, several sintered pellets of $\mathrm{UO}_{2} \mathrm{muO}_{2}$ in the composition range 0.5 to $10 \mathrm{w} / \mathrm{O} \mathrm{PuO}_{2}$ were exposed to $750 \mathrm{~F}-2200 \mathrm{psi}$ stean for ten hours. Controls consisting of $\mathrm{VO}_{2}$ pellets previously corrosion tested and found acceptable were also run simultaneously. All pellets showed no visual evidence of corrosion.

Short-Term Irradiation Test Fuel Fabrication

(M. D. Houston, M. Zambernard)

During this quarter, fuel element fabrication and testing for the shortterm irradiation specimens was completed (see Task 5.00). In all, a total 
Table 4.1

Density of Sintered Pellets for Corrosion Studies

\begin{tabular}{|c|c|c|}
\hline Composition & $\begin{array}{r}\text { Density } \\
\left(\mathrm{gm} / \mathrm{cm}^{3}\right) \\
\end{array}$ & Percent Theoretical \\
\hline $\mathrm{PuO}_{2}$ & $10.30-10.44$ & $90.0-91.1$ \\
\hline $\mathrm{UO}_{2}-80 \mathrm{v} / \mathrm{OPuO}_{2}$ & $9.44-9.60$ & $83.1-84.5$ \\
\hline $\mathrm{UO}_{2}-35 \mathrm{w} / \mathrm{PuO}_{2}$ & $10.13-10.24$ & $91.0-91.9$ \\
\hline $\mathrm{UO}_{2}-17.8 \mathrm{~m} / \mathrm{O} \mathrm{PuO}_{2}$ & $10.60-10.81$ & $96.0-97.8$ \\
\hline $\mathrm{UO}_{2}-12.5 \mathrm{~m} / \mathrm{O} \mathrm{PuO}_{2}$ & $10.47-10.59$ & $94.8-95.9$ \\
\hline $\mathrm{UO}_{2}-5 \mathrm{w} / \mathrm{O} \mathrm{PuO}_{2}$ & $10.30-10.45$ & $93.7-95.2$ \\
\hline $\mathrm{UO}_{2}-0.5 \mathrm{~m} / \mathrm{O} \mathrm{PuO}_{2}$ & $10.26-10.53$ & $93.5-96.0$ \\
\hline
\end{tabular}


NUHEC $P-104$

of eighty fuel elements have been prepared for both in-reactor and library samples. Representative pellets of the various compositions and density ranges, seventeen variables in all, are undergoing chemical, metallographic, and $x$-ray diffraction examination to provide complete pre-irradiation characterization. 
NUMEC $P=104$

\section{RADTATION TESTING AND EVALUATION}

Task 5.00

Lo J\& Jones

Short-Term Irradiation Tests

(Lo Jo Jones, R. Mo Horgos)

Fourteen aluminum capsules have been loaded with three stainless clad $\mathrm{PuO}_{2}-\mathrm{UO}_{2}$ fuel elements each together with the appropriate amount of $\mathrm{NaK}$ further, all capsules have been welded, satisfactorily leak-tested, and shipped to the reactor site.

Hot Laboratory Eguipment Fabrication

(R.M. Horgos)

The Junior Cave is being modified to pernit relatively easy installation of the specially designed alpha box that will house the equipment required for chemical separations and burnup analysis. The irradiated bulk fuel will be sampled, dissolved, and aliquoted in the alpha boxes wi thin the high level cell and transferred to the Junior Cave facility as relatively low level liquid samples. In particular, the front shield of the Junior Cave has been redesigned to open to the side, completely out of the way, to permit insertion and removal of the alpha box nounted on a stand which rolls on casters. The Junior Cave has been positioned in its proper location in the hot handling area, and installation of the door mechanism will be started as soon as the necessary structures and hardware are received. Central Research Laboratories Model 7 Master Slave manipulators are being installed for use in this facility.

Design of the alpha enclosure for the Junior Cave has been completed and includes such general features as a 14 inch diameter bag out port, cylindrical exhaust and inlet plenums for enclosure of high efficiency filters, a shielded storage cave, a scrap disposal tube, a centrifuge pod, and a sphincter valve. Fabrication of this box together with the support stand has been started. The shielded transfers to this box wil be performed with special transfer casks designed for use with the sphincter valve.

All general modifications to the shielded steel metallographic cell required for incorporation of the alpha enclosure have been completed. The metallographic mounting press, automatic polishing wheels, electrolytic cell for etching, and miscellaneous shelving and hand tools have been installed in the alpha box. Facilities for later installation of a cathodic vacuun etcher have been incorporated. Entrance to this box will be by a sphincter valve, alr lock, or bag-in. The latter can only be accomplished when the 
NUIEC Pas 104

alpha box is removed from the shielded cell and therefore is not applicable for transfer of irradiated material. A specially designed cask to transfer sphincter cans from the high level cells to the metallographic cell has been designed.

Shielding panels (4" thick lead) and a shielded access door for the Bausch and Lomb Metallograph have been designed and fabrication started. Support stands for the metallograph and for the lead shielding also are being fabricated.

AII required modifications to the hot cell alpha boxes have been corpleted. The box ventilation system has been nodified to minimize the pressure drop through the systen since tests on the original systen resulted in low air flow through the individual box exhaust fans and insufficient cooling of the in-line fan motors. Optical viewing ports for examination and photography of irradiated samples utilizing a thru-wall periscope vere also added in the top of each box.

Design of the garma scan equipment has been completed and fabrication started. Installation of this equipkent will complete Alpha Box 1 , which contains, in addition, the capsule opening equiprent, a tubing cutter for specimen sectioning, and a dianond cuto off wheel.

Construction of the fission gas system is continuing The out of of cell collection system is being constructed and will be protected from alpha contanination by a micrometallic filter at the alpha box connection. Initially, the only in box equipment required to perform the post-irradiation annealing studies are a furnace and a vacuum-tight furnace tube. However, provisions in the box for later installation of a puncturing device to puncture the cladding of high bumup oxide fuel elements under a closed vacuur system are being made. This puncturing device has been designed but has not as yet been fabricated.

A major concern in the utilization of the alpha boxes had been the plastic boots for the nanipulators. The first models that vere obtained were poorly constructed at the point where the manipulator jar attached to the main arm of the manipulator. This resulted in gross tearing at this point, increasing the possibility of releasing contarination to the room. Other models of booting, utilizing new fabrication techniques, have been obtained, and these are now being rested. 


\section{REACTOR PHYSTCS AND FHCINEERING PARANETRIC STUDTES}

Task 8.00

J. Do Clement

\section{Assessment of Plutonium in Near-Thermal Reactors \\ (W. J. Ross, Jo Ruzbacki)}

Modification of the NUSURP code to allow calculation of undermoderated systems has been completed. The nodification involved the extension of Arister s compilation of cross sections averaged over the Wignerwilkins spectrum (SOFOCATE code), WAPD-185, to include larger values of plutoniun to-hydrogen ratios and higher temperatures and the programing of these values into the NUSURP code.

Experinental data on uranium lattice measurements as well as analytucal data derived from NUFT, REPETITIOUS and SOFOCATE codes are now being analyzed to check the ralidity of the IUSUURP code in the undermoderated region, prior to analysis of plutonium behavior in such systems.

$$
\text { (J. } \frac{\text { Fast Reactor Survey }}{\text { D. Clement, Jo Ruzbacki) }}
$$

To allow rapid assessment of fuel behavior in fast reactors, a program has been initiated to develop a sumplified wodel for describing the nuclear behavior of fast reactors. For performing general parametric studies, as contrasted with detailed design work, it is desirable to use a simplified model that will exhibit the salient nuclear behavior without requiring long and expensive computational time. In other words, a neutronics model is needed for fast reactors comparable to the IJUSURP description developed for thermal reactors. As presentiy conceived, the simplified fast reactor model will have the folloung subroutines:

1) Calculate infinite mediun spectrum The input will consist of aton densities for a honogenized region. A Iibrary of energy dependent cross sections will be required.

2) Obtain spectrum areraged "fast group" cross sections from results of the first subroutine.

3) Solve multi-region, few group diffusion equation for reactivity and flux shapes. Fach region will be represented by diffusion theory constants obtained from results of the second subroutine.

Presently, programing of the first subroutine for the RPC-4000 computer is nearing completion. 